\title{
AN AXISYMMETRIC FINITE-DIFFERENCE FLOW MODEL TO SIMULATE DRAWDOWN IN AND AROUND A PUMPED WELL
}

By A.T. Rutledge

\section{U.S. GEOLOGICAL SURVEY}

Water-Resources Investigations Report 90-4098

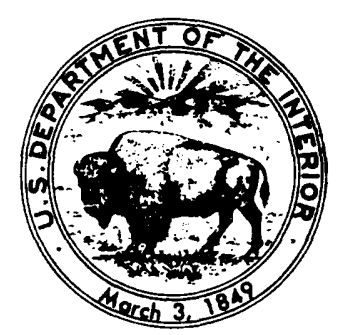

Lawrence, Kansas

1991 


\section{U.S. DEPARTMENT OF THE INTERIOR \\ MANUEL LUJAN, JR., Secretary \\ U.S. GEOLOGICAL SURVEY \\ Dallas L. Peck, Director}

For additional information write to:

Copies of this report can be purchased from:

District Chief

U.S. Geological Survey

U.S. Geological Survey

Water Resources Division

Books and Open-File Reports

4821 Quail Crest Place

Denver Federal Center, Bldg. 810

Box 25425

Lawrence, Kansas 66049

Denver, Colorado 80225 


\section{CONTENTS}

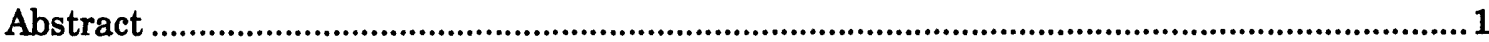

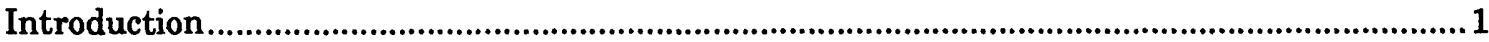

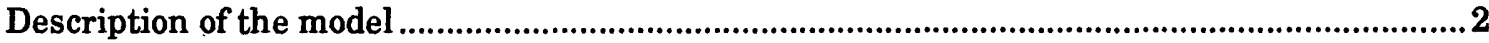

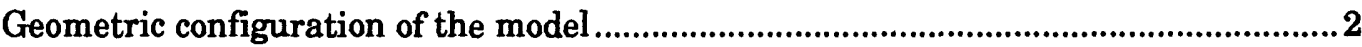

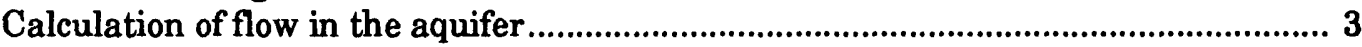

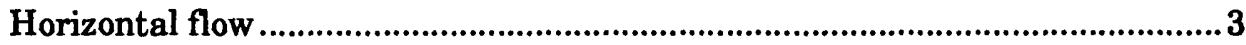

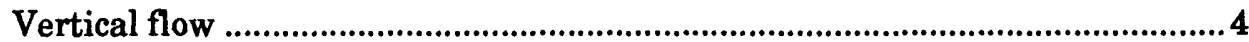

Treatment of cells in top layer.............................................................................5

Calculations of drawdown and hydraulic-head loss .............................................5

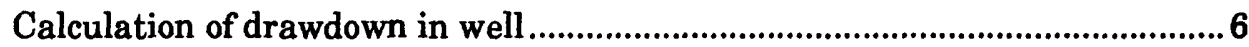

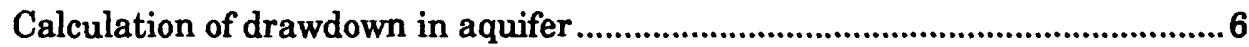

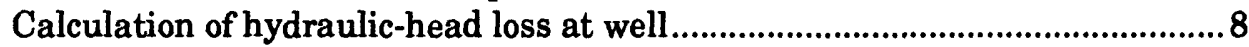

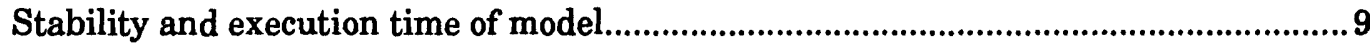

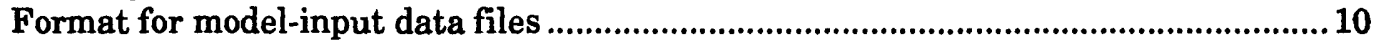

Comparison of model results with analytical solutions ................................................... 10

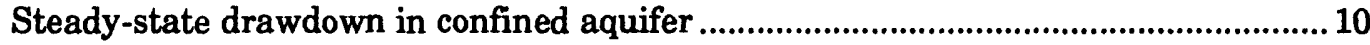

Nonsteady drawdown in nonleaky confined aquifer .......................................................11

Drawdown in leaky confined aquifer ignoring storage in confining layer...................11

Drawdown in leaky confined aquifer considering storage in confining layer..............11

Drawdown induced by partially penetrating well in unconfined aquifer considering

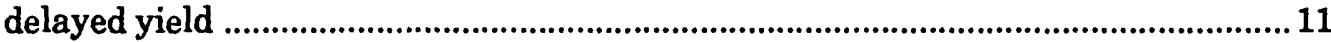

Drawdown in large-diameter well .................................................................................. 11

Comparison of model results with results of another numerical model .................................16

Complications induced by well characteristics................................................................ 18

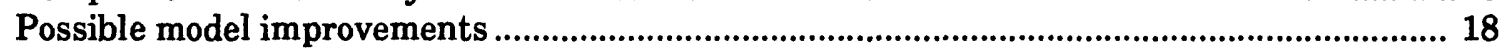

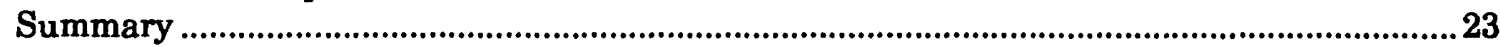

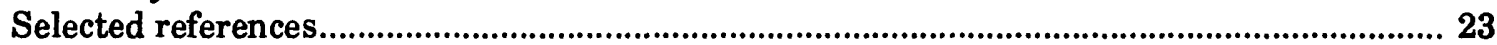

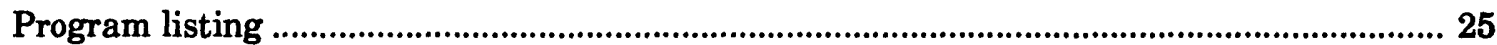




\section{ILLUSTRATIONS}

Figure $\quad$ Page

1. Diagram showing near-well geometric configuration of the axisymmetric model ........2

2. Diagram showing conceptualization of horizontal flow from center of one cell to center of next

3. Diagram showing variables needed in calculation of thickness-weighted harmonic mean of hydraulic-conductivity values for two adjacent cells, used to calculate vertical flow between two cells ......................................................................................5

4. Diagram showing procedures executed by model during one time step .........................7

5. Diagram showing model configuration, input data file, and drawdown results determined from Thiem equation and axisymmetric model.

6. Diagram showing model configuration, input data file, and graphical results of drawdown determined from the Theis equation and the axisymmetric model ........... 13

7. Diagram showing model configuration, input data file, and graphical results of drawdown determined from the Hantush-Jacob method and the axisymmetric model.

8. Diagram showing model configuration, input data file, and graphical results of drawdown determined from Hantush method considering storage in confining layer and the axisymmetric model.

9. Diagram showing model configuration, input data file, and graphical results of drawdown determined from the Neuman method and the axisymmetric model ........ 16

Figure 10-14. Graph showing:

10. Relation between drawdown and time within and near a pumped well that has 0.785398 square foot of free water surface

11. Results of drawdown computed by the Reilly model and the axisymmetric model.

12. Drawdown in and near a pumped well that fully penetrates a homogeneous, isotropic, confined aquifer under conditions similar to Cooley and Cunningham (1979)

13. Drawdown in and near a pumped well that is open to homogeneous, isotropic, unconfined aquifer

14. Drawdown in and near a pumped well that is open to three different zones in a heterogeneous, anisotropic aquifer system 


\section{CONVERSION FACTORS}

\section{Multiply}

foot

square foot

cubic foot per second

foot squared per second

foot per second per foot
By

0.3048

0.09290

28.32

0.0929

1.0

\section{To obtain}

meter

square meter

liter per second

meter squared per second

meter per second per meter 


\title{
AN AXISYMMETRIC FINITE-DIFFERENCE FLOW MODEL TO SIMULATE DRAWDOWN IN AND AROUND A PUMPED WELL
}

\author{
By A.T. Rutledge
}

\section{ABSTRACT}

An axisymmetric finite-difference model was developed that can simulate drawdown in three dimensions in and around a pumped well. Well properties that can be simulated include well-casing storage, hydraulic-head loss across the well screen, and hydraulic-head variation along the length of the well bore due to pipe-flow friction and nonuniform velocity. The model allows for partial well penetration and for multiple screened intervals. The fraction of total inflow to the well that is allocated to each aquifer layer is a variable that is calculated in each time step. Aquifer properties that can be simulated include confined conditions (leaky or nonleaky), unconfined conditions, vertical-horizontal anisotropy, and vertical variations in hydraulic conductivity.

Horizontal flow is calculated from an integration of Darcy's law to allow for the variation in cross-sectional area from one finite-difference cell to the next. The uppermost layer of finite-difference cells, which represents the upper part of the saturated zone, contributes stored water from specific yield, whereas other cells contribute stored water from specific storage. This representation allows for simulation of the "delayed-yield" effect. Calculation of horizontal flow in the uppermost layer of cells allows for the reduction in cross-sectional area (and transmissivity) caused by lowering of the water table.

The model requires horizontal uniformity of hydraulic conductivity, specific yield, and specific storage. The model also requires that the upper layer of cells must be thicker vertically than the maximum drawdown of the water table, and that the seepage face is not simulated. The geometric configuration requires the pump intake to be above the top of the well screen. An upper limit on timestep length required by the explicit method can result in lengthy execution time.

Several different aquifer properties and numerous complexities in the flow system that are caused by well characteristics can be simulated. All characteristics can be allowed for simultaneously. The model was tested by comparing its results with results of published analytical solutions and other mathematical models. The results were generally in good agreement.

\section{INTRODUCTION}

Because the analytical methods used to interpret drawdown data from aquifer tests require one or more assumptions about the pumped well and the aquifer system that may not be realistic, numerical models may prove more useful. This report describes a numerical model that can simulate simultaneously the effects of well properties, such as partial penetration and multiple screened intervals; processes at the well, such as the derivation of water from well-casing storage, hydraulic-head loss across the well screen, and hydraulic-head variation along the length of the well bore caused by pipe-flow friction and nonuniform velocity; ground-water system properties, such as multiple aquifers, confined conditions (leaky and nonleaky), unconfined conditions, verticalhorizontal anisotropy, and vertical variation in hydraulic conductivity; and processes in the ground-water system, such as delayed yield and the reduction in saturated thickness caused by water-table drawdown. The purpose of the model is to provide another tool for interpreting aquifer-test data that are complicated by one or more of these properties and processes.

A number of ground-water models that simulate axisymmetric flow around a pumped well are described in the literature. Cooley and Cunningham (1979) described a finite-element model that computes hydraulic-head losses across the well screen and along the well bore. A model constructed by Davis and Neuman (1983) allows simulation of well-bore storage and the seepage face. Reilly (1984) described a finiteelement model that simulates confined or unconfined conditions and multiple aquifers. 
DESCRIPTION OF THE MODEL

\section{Geometric Configuration of the} Model

The model is described as axisymmetric because the framework of finite-difference cells is symmetrical with respect to an axis, which is the centerline of the well. The geometric configuration of the axisymmetric model is shown in figure 1 . Rows (I) represent horizontal aquifer layers, and columns (J) represent cylindrical shells that are concentric with the centerline of the well. The user specifies the vertical thickness of each layer, the horizontal thickness of column 1, and a column-thickness multiplier for all subsequent columns. The elements defined by a combination of row and

WELL

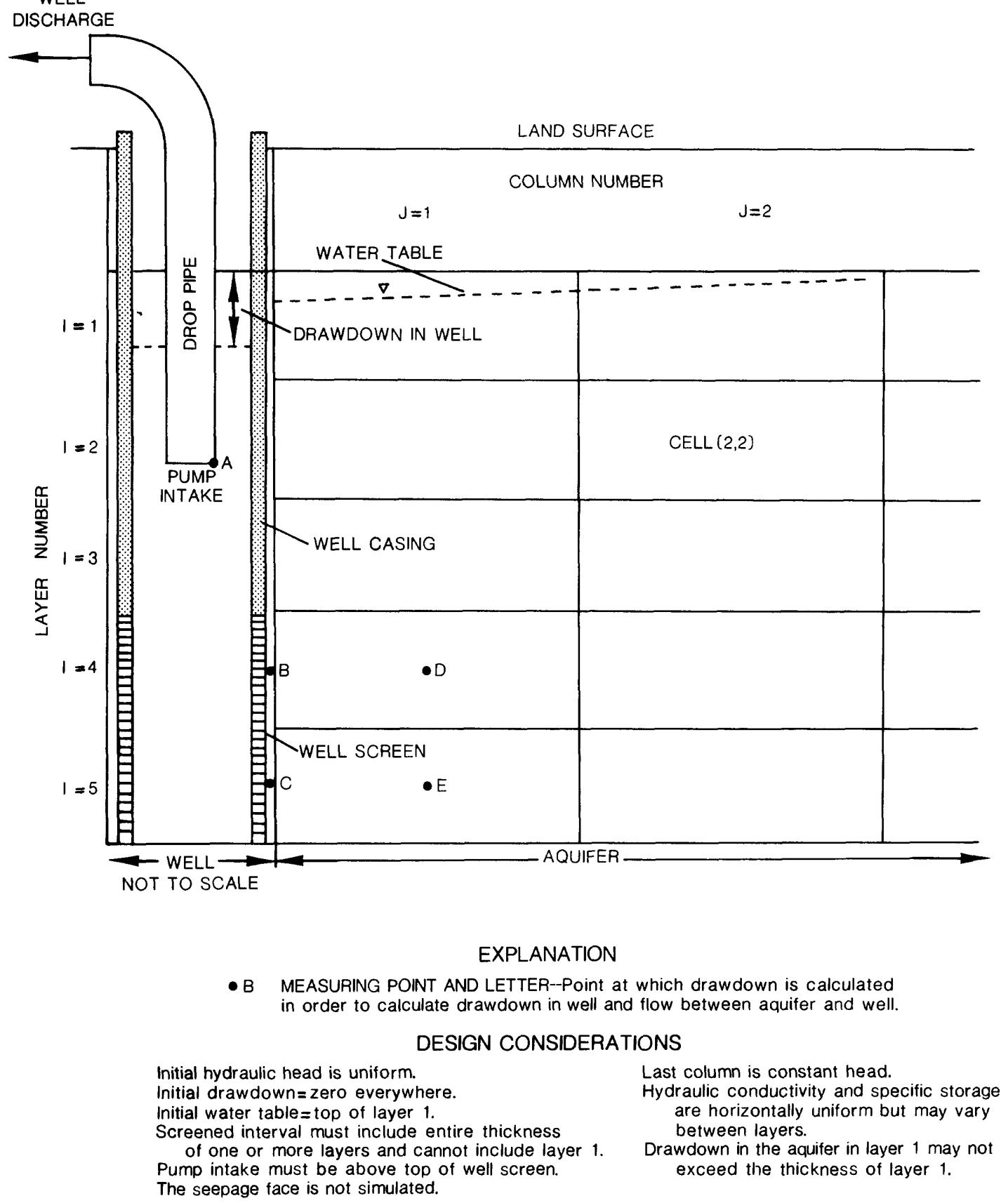

Flgure 1. Near-well geometric configuration of the axisymmetric model. 
column number are called cells. The actual shape of the cells in space is similar to a horizontal wheel.

\section{Calculation of Flow in the Aquifer}

Flow in the aquifer can be identified as either horizontal or vertical between adjacent cells. It is generally conceptualized as the flow between the midsection of one cell and the midsection of the next (cell-centered formulation), where both midsections are perpendicular to the direction of the flow to be calculated and where the midsections define the entire cross-sectional areas of the cells. Slight variations in this general conceptualization for flow near the well and for flow near the water table will be explained.

In the simplest form, the flow from one finite-difference cell to another can be expressed by an adaptation of Darcy's law (given that zero drawdown in all points of the system can be equated with zero gradient throughout the system):

$$
Q=(K)(A) \frac{d(D D)}{d X}
$$

where

$$
\begin{aligned}
Q= & \text { flow }\left(\mathrm{L}^{3} \mathrm{~T}^{-1}\right) ; \\
K= & \begin{array}{l}
\text { hydraulic conductivity in the direction } \\
\text { of flow }\left(\mathrm{LT}^{-1}\right) ;
\end{array} \\
A= & \begin{array}{l}
\text { cross-sectional area of the cells } \\
\text { perpendicular to the direction of flow } \\
\left(\mathrm{L}^{2}\right) ;
\end{array}
\end{aligned}
$$

$$
\begin{aligned}
& D D=\text { drawdown (L); and } \\
& X=\text { distance in direction of flow (L). }
\end{aligned}
$$

If the cross-sectional area of flow and hydraulic conductivity are constant in space, then the gradient $d(D D) / d X$ may be considered uniform between the two cells, and, considering this to be a cell-centered formulation, the flow can be obtained by substituting the difference in drawdown between the center points of the two cells for $d(D D)$, and the distance between the center points of the two cells for $d X$.

\section{Horizontal Flow}

In the axisymmetric model, horizontal flow is radial flow, and the cross-sectional area of flow $(A)$ varies from one cell to the next (fig. 2). Radial flow between adjacent cells can be viewed as the flow from one end of a trapezoidal prism to another, where the opposite ends of the trapezoidal prism represent the midsections (dotted lines in figure 2) of the cells and where the cross-sectional area of flow varies linearly with $X$ (fig. 2). To derive an expression for the flow from one cell to the next, consider $X=0$ at the midsection of cell 1 and $X=L$ at the midsection of cell 2. Also consider $D E L D D$ to be the drawdown at the center of cell 2 minus drawdown at the center of cell 1 . Because hydraulic properties are horizontally uniform in this model, hydraulic conductivity $(K)$ is the same in the two cells. Substituting and rearranging equation 1 , then integrating from $X=0$ to $X=L$ :

$$
Q=\frac{(D E L D D)(K)}{\int_{X=0}^{X=L} \frac{d X}{A(X)}}
$$

where

$$
L=\text { the distance between the }
$$
midsections of the two cells $(L)$; and

$A(X)=$ a mathematical expression for the cross-sectional area as a function of $\boldsymbol{X}$ :

$$
A(X)=A 1+\frac{(A 2-A 1)}{(L)} X,
$$

where

$$
\begin{aligned}
A 1= & \text { cross-sectional area of flow at the } \\
& \text { midsection of cell } 1\left(L^{2}\right), \text { and } \\
A 2= & \text { cross-sectional area of flow at the } \\
& \text { midsection of cell } 2\left(L^{2}\right) .
\end{aligned}
$$

Substituting this expression into equation 2 , the general solution of equation 2 is the following, which is similar to the Thiem equation (Lohman, 1972):

$$
Q=\frac{(D E L D D)(K)(A 2-A 1)}{(L)[\ln (A 2)-\ln (A 1)]} .
$$

If the flow between a cell in column 1 (fig. 1) and 


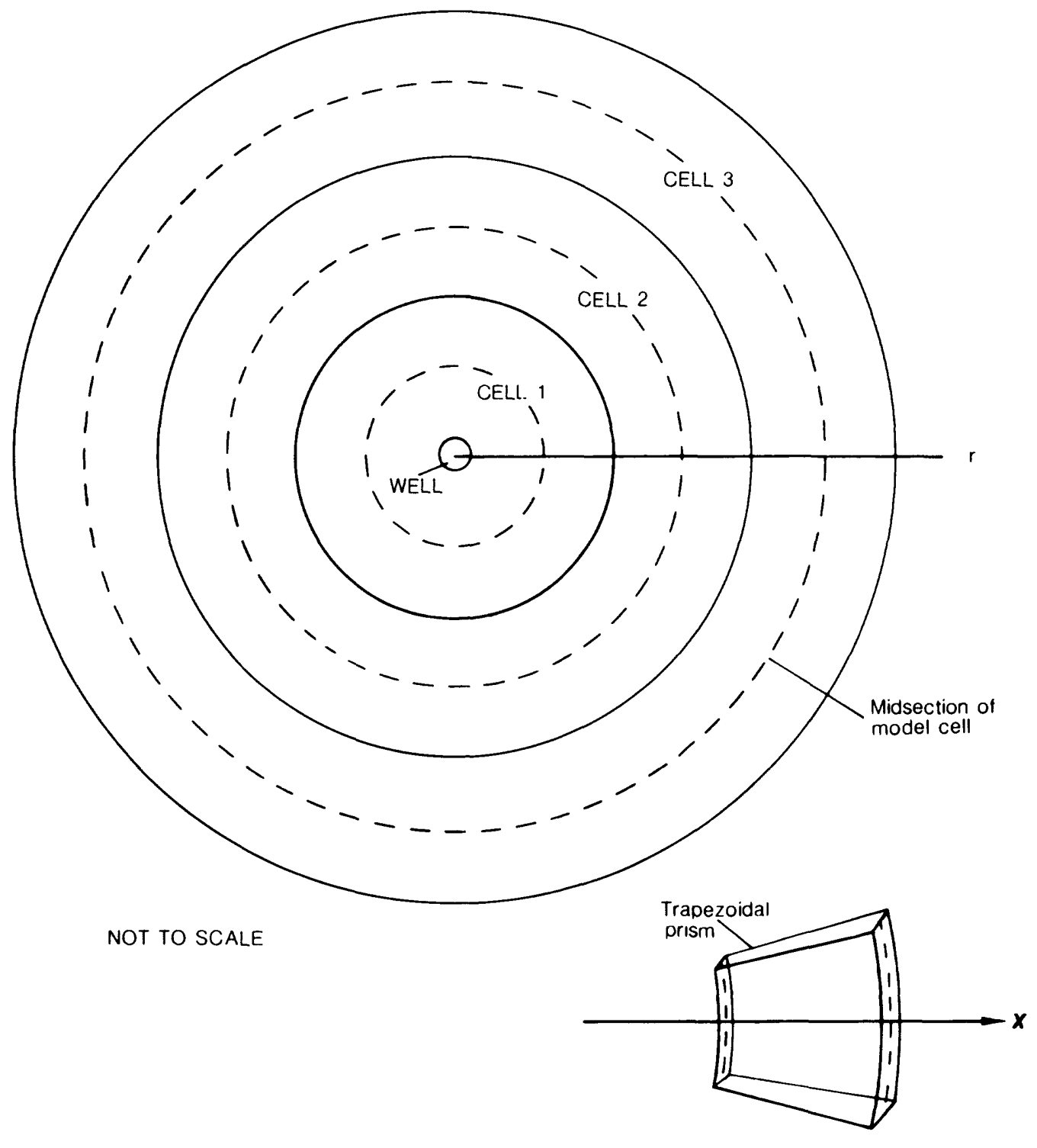

Figure 2. Conceptualization of horizontal flow from center of one cell to center of next. Flow may be conceptualized as flow from one end of a trapezoidal prism to another because the cross-sectional area of flow varies linearly with $X$.

the well is being calculated, the flow is conceptualized to be from the midsection of the cell in column 1 to the outside of the well, and $A 2$ equals the cross-sectional area of flow at the outside of the well.

\section{Vertical Flow}

In vertical flow between two cells, the crosssectional area is a constant, but the calculation of flow can be complicated by variations in vertical hydraulic conductivity from one cell to the next (fig. 3). Considering the flow at an instant in time to be the same in both cells, the flow from one cell to the next may be calculated using the thickness-weighted harmonic mean $(\bar{K})$ of two hydraulic-conductivity values:

$$
\bar{K}=\frac{L}{\frac{L a}{K a}+\frac{L b}{K b}}
$$

where 


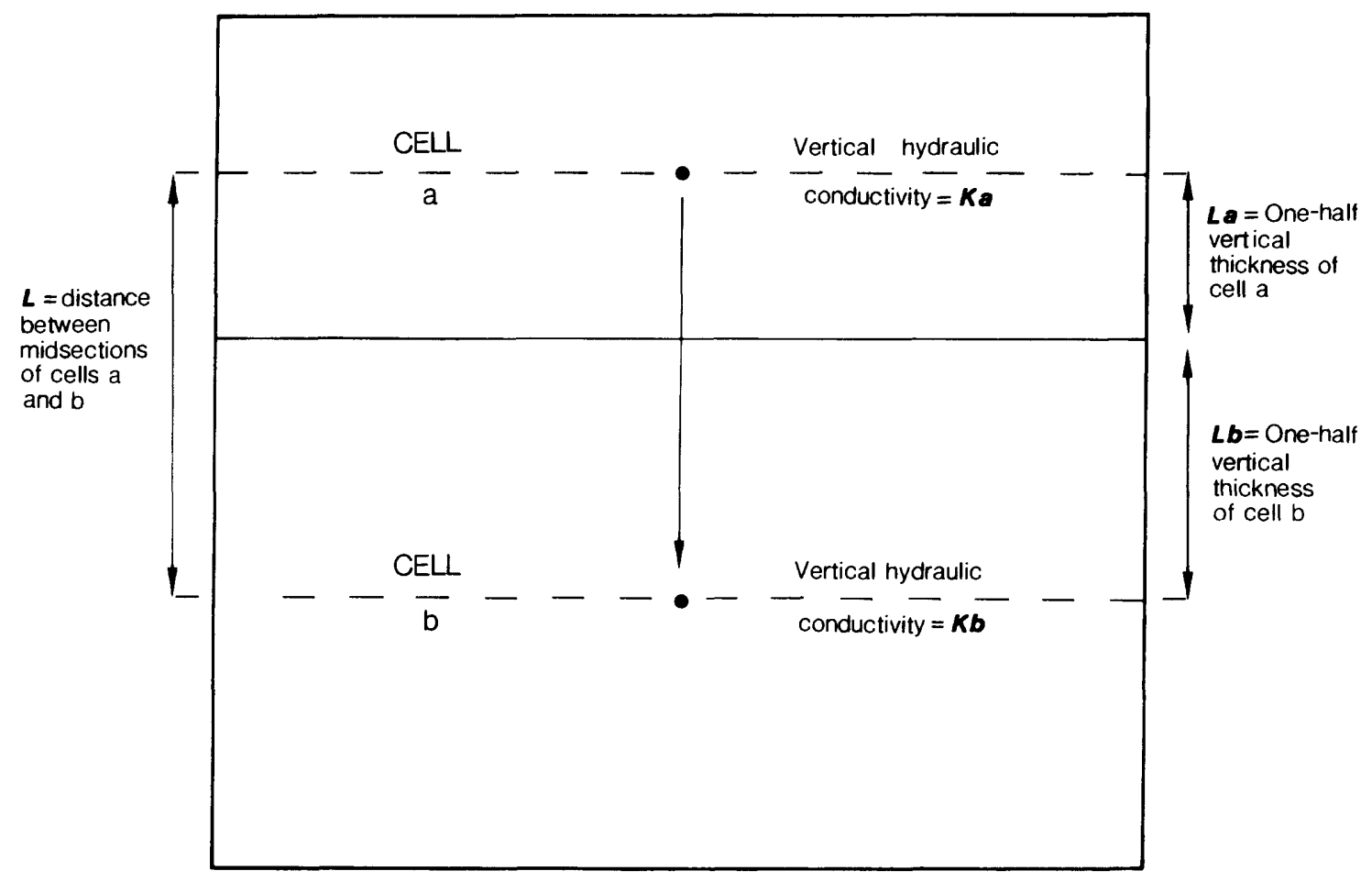

NOT TO SCALE

Flgure 3. Variables needed in calculation of thickness-weighted harmonic mean of hydraulic-conductivity values for two adjacent cells, used to calculate vertical flow between two cells.

$L=$ total distance between midsections of the two cells $(\mathrm{L})$;

$K a=$ vertical hydraulic conductivity of cell a $\left(\mathrm{LT}^{-1}\right)$;

$K b=$ vertical hydraulic conductivity of cell b $\left(\mathbf{L T} \mathbf{T}^{-1)}\right.$;

$L a=$ one-half the vertical thickness of cell a (L); and

$L b=$ one-half the vertical thickness of cell $b$ (L).

Calculations of vertical flow between adjacent cells are derived from:

$$
Q=(\bar{K})(A) \frac{(D E L D D)}{L},
$$

where $A$ is the cross-sectional area of flow. If the vertical hydraulic conductivity is zero in either of the two cells, the model skips both equations 5 and 6 , and sets the vertical flow $=0$.

\section{Treatment of Cells in Top Layer}

The treatment of flow in cells in the top layer of the aquifer differs from that of other cells in two ways:

(1) The cross-sectional area of horizontal flow varies with time because drawdown in this layer causes the flow field to constrict. This causes a change in transmissivity due to drawdown of the water table.

(2) In the calculations required to determine the flow between a cell in the top layer and a cell in the next layer down (equations 5 and 6 ), $L$ is the distance between the water table and the center of layer 2, instead of the distance between the midsections of the cells.

\section{Calculations of Drawdown and Hydraulic-Head Loss}

The modeling process is divided into multiple time steps, the number and duration of 
which are designated by the user. Procedures executed by the model during one time step are diagramed in figure 4 . To complete the simulation of drawdown at the end of a time step, the model uses an iterative method.

\section{Calculation of Drawdown in Well}

In each iteration, the first calculation is the new drawdown in the free water surface in the well ( $D D W E L L)$. The value of $D D W E L L$ is equal to the drawdown at the pump intake. Holding drawdown in all aquifer cells constant, the following equation is solved for $D D W E L L$ by a trial-and-error method:

$$
\begin{aligned}
& Q W=\frac{(\text { FWAREA) (DDWELL-BEGINW) }}{T S L}+ \\
& \sum_{I=1}^{N Z} \frac{[S C R(I)][D E L D D(I)][K H(I)][A 2(I)-A l(I)]}{(L E N G T H)[\ln A 2(I) \cdot \ln A l(I)},
\end{aligned}
$$

where

$Q W \quad=$ well discharge $\left(\mathrm{L}^{3} \mathrm{~T}^{-1}\right) ;$

FWAREA = area of free water surface in the well casing $\left(\mathrm{L}^{2}\right)$;

$D D W E L L=$ new drawdown in free water surface in well at end of the time step (L);

$B E G I N W=$ old drawdown in free water surface in well at beginning of the time step (L);

TSL = length of time step (T);

$N Z \quad=$ number of layers;

$S C R(I)$ = an indicator array, where $\operatorname{SCR}(I)=1$ if the well is open to layer I, and 0 otherwise;

$D E L D D(I)=$ increase in drawdown from mid section of column 1 (in layer $I$ ) to a point just outside the well (in layer $I)(\mathrm{L})$;

$K H(\mathrm{I}) \quad=$ horizontal hydraulic conductivity in layer $I\left(\mathrm{LT}^{-1}\right)$;

$L E N G T H=$ distance from the outside of well to the midsection of column 1 (L);

$A 2(I) \quad=$ cross-sectional area through which water flows at the outside of the well in layer $I\left(\mathrm{~L}^{2}\right)$; and

$A 1(I) \quad=$ cross-sectional area through which water flows at the midsection of column 1 in layer $I\left(L^{2}\right)$.

The first term on the right side of the equation is the water obtained from reduction in well-casing storage. The second term (adapted from equation 4) is the total inflow to the well from all aquifer layers open to the well. $D E L D D(I)$ is the increase in drawdown between points $D$ and $B$ for layer 4 , or between points $E$ and $\mathrm{C}$ in layer 5 (fig. 1). It is obtained from:

$$
\operatorname{DELDD}(I)=D D W E L L-A D J U S T(I)-D D(I, 1),(8)
$$

where ADJUST $(I)$ is the increase in drawdown from the outside of the well, for layer $I$, to the pump intake--for example, from point $B$ to point A for layer 4, or from point $C$ to point $A$ for layer 5 (fig. 1). The drawdown of the free water surface in the well (DDWELL) is equal to the drawdown at point $A$ in figure 1 . The values for the array "ADJUST" are set to 0 before the first time step and are recalculated at the end of each time step by methods that will be explained in subsequent paragraphs.

\section{Calculation of Drawdown in Aquifer}

When equation 7 is solved for $D D W E L L$, values are assigned to drawdown just outside the well for all layers exposed to the aquifer (such as points $B$ and $C$ in fig. 1). The drawdown just outside the well in layer $I(D D)$ is:

$$
D D=D D W E L L-A D J U S T(I)
$$

While drawdown just outside the well is held constant, calculations of new drawdown in each aquifer cell take place using equation 10 or 11. Both of these equations state that the loss in stored water in the cell (the left side of the equations) is equal to the algebraic sum of the terms that each express outflow from the cell (the right side of the equations). Therefore, 


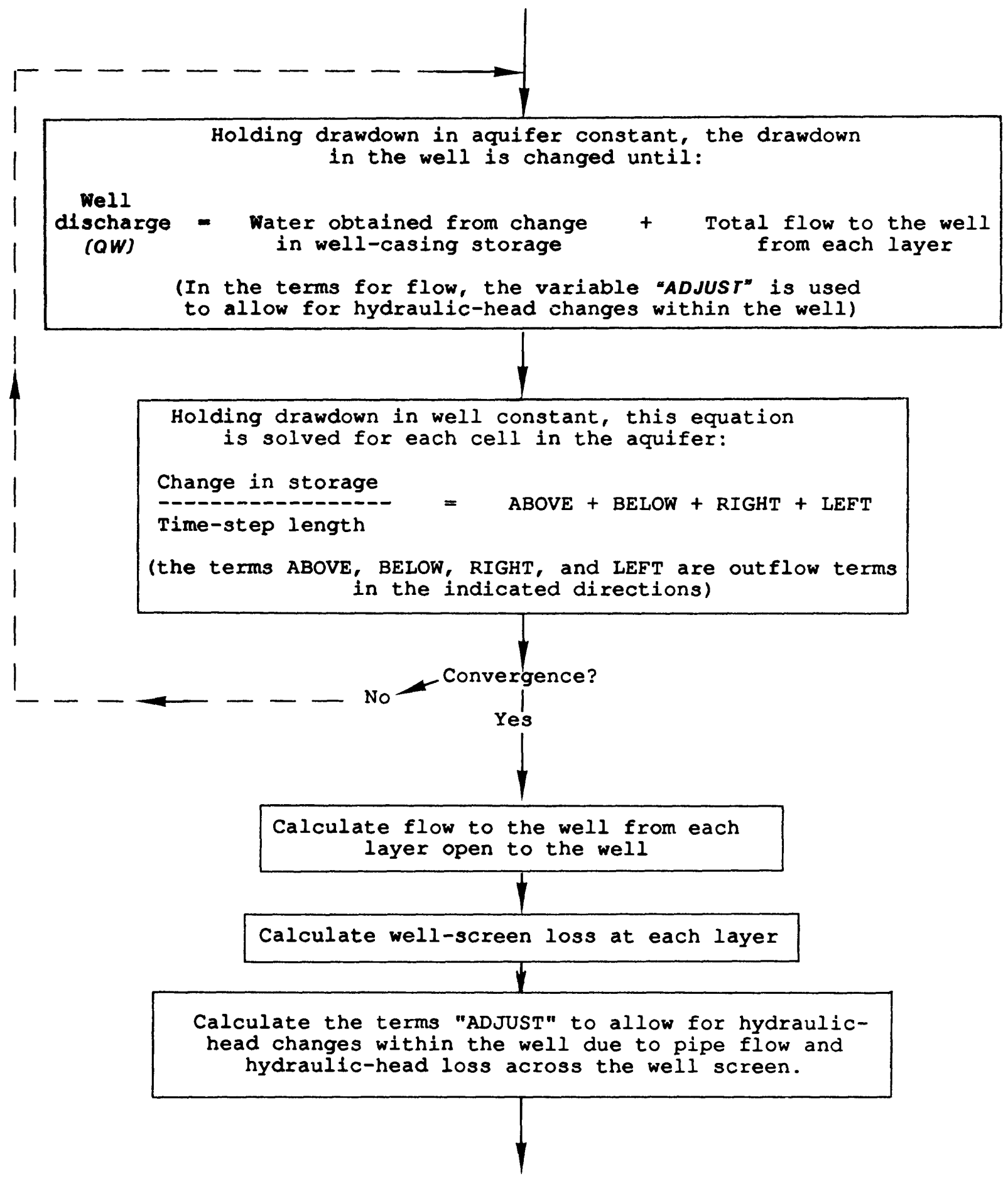

Figure 4. Procedures executed by model during one time step. 
if $I=1$ :

$$
\begin{aligned}
& \frac{[D D(I, J)-B E G I N(I, J)](\pi)(S Y A)\left[(R(J+1))^{2}-(R(J))^{2}\right]}{T S L} \\
& =B E L O W+R I G H T+L E F T ;
\end{aligned}
$$

if $\mathrm{I}>1$ :

$\frac{[D D(I, J)-B E G I N(I, J)](\pi)(S S(I))(D E L Z(I))\left[(R(J+1))^{2}-(R(J))^{2}\right]}{T S L}$

$=$ ABOVE + BELOW + RIGHT + LEFT ;

where

$$
\begin{aligned}
D D(I, J)= & \begin{array}{l}
\text { new calculated drawdown } \\
\text { at the center of cell }(I, J) \\
\\
(L) ;
\end{array} \\
B E G I N(I, \mathrm{~J})= & \begin{array}{l}
\text { drawdown at the same } \\
\text { location at the beginning of } \\
\text { the time step }(\mathrm{L}) ;
\end{array}
\end{aligned}
$$
$\operatorname{BEGIN}(I, \mathrm{~J})=$ drawdown at the same location at the beginning of the time step (L);
SYA = the apparent specific yield (dimensionless);

$R(J+1)=$ distance from the center of the well to the side of the cell that is farthest from the well (L);

$R(J)=$ distance from center of the well to the side of the cell that is closest to the well (L);

TSL = length of time step (T);
$S S(I)=$ specific storage of layer $I$ $\left(\mathrm{L}^{-1}\right)$; and

$D E L Z(I)=$ vertical thickness of layer $I$ (L).

The variables ABOVE and BELOW, which are assigned values using equation 6 , are vertical flows out of the cell in the indicated directions. The variables RIGHT and LEFT, which are assigned values using equation 4 , are the horizontal flows out of the cell away from the well and toward the well, respectively. In the calculation of all four variables ABOVE, BELOW, RIGHT, and LEFT, it is the drawdown in the adjacent cell minus the drawdown in the "present" cell that is used to calculate hydraulic- head difference between the cells ( $D E L D D$ in equations 4 and 6). The storage term for cells in the top layer is derived from apparent specific yield (SYA, equation 10), whereas that of the other cells is derived from specific storage (SS, equation 11). The assumption here is that water derived from specific storage is negligible in comparison with water derived from specific yield in the top layer.

The iterative procedure used to calculate the new drawdown at each aquifer cell using equations 10 or 11 consists of an orderly sweep through the entire array of cells except for cells in the last column. The program starts at $I=1$ and $J=1$ and sweeps across from left to right (increasing $J$ ) and down line by line (increasing $I)$ as if reading a page. In this explicit GaussSeidel method (Wang and Anderson, 1982, p. 2627), a new value for drawdown at a cell replaces the old value before the program goes on to the next adjacent cell.

When equation 7 has been solved for the new drawdown at the pump intake, equation 9 has been solved for the new drawdown outside the well, and equations 10 or 11 have been solved for the new drawdown at all aquifer cells, one iteration is complete. Now the model checks to see if it has converged to a solution. If the newly calculated drawdown at any point differs from its previous value by more than the userdesignated convergence criterion, then another iteration is started (return loop in figure 4). Otherwise, the newly calculated drawdowns represent drawdown at the end of the time step.

\section{Calculation of Hydraulic-Head Loss at Well}

When the above iterative procedures are complete, the model calculates conditions at the 
end of the time step. The total flow $(Q)$ to the well for the time step is:

$$
Q=Q W-\frac{(F W A R E A)(D D W E L L-B E G I N W)}{T S L} .
$$

Next, the hydraulic-head losses at the well are calculated. Work by Jacob (1947) indicates that the total hydraulic-head loss at the well, which is the sum of head loss across the well screen and head loss due to pipe flow up the well casing, is proportional approximately to the square of the well discharge. Rorabaugh (1953) stated that an exponent of 2.5 , instead of 2 , is more appropriate.

The model calculates hydraulic-head loss across the screen at each layer [SCNLOSS $(I)]$ using the expression:

$$
\operatorname{SCNLOSS}(I)=(C W)\left(\frac{Q L(I)}{[D E L Z(I)](R W)}\right)^{C N},
$$

where $C W$ and $C N$ are variables that depend on characteristics of the well screen; $Q L(I)$ is the flow to the well from layer $I ; D E L Z(I)$ is the vertical thickness of the layer; and $R W$ is the radius of the well. All are user-defined variables.

Next, the relative contributions to the well from each aquifer layer are calculated. These incremental contributions to the well enable the model to calculate the vertical pipe flow in the well between each layer, and thus, the incremental piezometric-head losses $(H L)$ along the pipe are calculated using the following formulation, which is obtained using a steadystate momentum balance, including the DarcyWeisbach formula for head loss due to friction along a pipe (from Streeter, 1950, p. 402):

$$
H L=(f) \frac{(L)}{(D)} \frac{\left(V_{1}\right)}{2 g}+\frac{V_{2}^{2}-V_{1}^{2}}{g},
$$

where

$H L=$ an incremental piezometric-head loss along a length of pipe (L);

$f \quad=$ a friction factor, usually obtained from experiment (dimensionless);

$L \quad=$ the length of pipe considered (L);

$V_{1}=$ velocity of flow at upstream position $\left(\mathbf{L T}^{-1}\right)$;
$V_{2}=$ velocity of flow at downstream position $\left(\mathbf{L T}^{-1}\right)$;

$D$ = diameter of the pipe (L); and

$g$ = gravitational constant $\left(\mathrm{LT}^{-2}\right)$.

Finally, the model calculates new values of $A D J U S T(I)$ for each layer to which the well is open $[S C R(I)=1]$, by combining results of equations 13 and 14 . These values are used in the beginning of the next time step (equation 8).

\section{Stability and Execution Time of Model}

The explicit finite-difference approximation used in this model is stable if, as the solution progresses forward through each time step, the errors are not amplified such that the solution becomes invalid (Wang and Anderson, 1982, p. 70). For a two-dimensional areal ground-water flow model made up of a grid in which the cell spacing is the same in both dimensions, stability depends on the following condition, adapted from Rushton and Redshaw (1979):

$$
T S L \leq \frac{0.25\left(d^{2}\right)(S S)}{(K)},
$$

where

$$
\begin{aligned}
& T S L=\text { length of time step }(\mathrm{T}) ; \\
& a=\begin{array}{l}
\text { width and length of the finite- } \\
\text { difference cells }(\mathrm{L}) ;
\end{array} \\
& S S=\text { specific storage }\left(\mathrm{L}^{-1}\right) ; \text { and } \\
& K=\text { hydraulic conductivity }\left(\mathrm{LT}^{-1}\right)
\end{aligned}
$$

To adapt equation 15 to the geometry of the axisymmetric model, the term $a^{2}$, which is the area of the cells in the areal model, is replaced with $(D E L R)(D E L Z)$, the corresponding term for the axisymmetric model, where $D E L R$ and $D E L Z$ are the dimensions of the axisymmetric model cells in the horizontal and vertical directions, respectively. Substituting the above into equation 15 results in the following requirement of time-step length:

$$
T S L \leq \frac{0.25(D E L R)(D E L Z)(S S)}{K} .
$$

Because this stability requirement must be 
met for all cells, the model user needs to first consider the cells for which the horizontal and vertical cell dimensions are smallest and for which hydraulic conductivity is largest. In other words, the test for stability needs to be applied first on the most permeable and vertically thinnest cells in column 1 (fig. 1).

Equation 16 was derived from stability requirements for areal finite-difference models. It was found by experimentation that the stability requirement for the axisymmetric model for the test problems considered is

$$
T S L \leq \frac{0.14(D E L R)(D E L Z)(S S)}{K} .
$$

If the time-step length is too long, the program will terminate execution. Termination occurs when a user-designated limit for the number of trials in the calculation of well drawdown or for the number of iterations is exceeded. The termination of the program due to instability usually will occur early in the simulation because the rate of hydraulic-head change is largest soon after pumping is initiated. Therefore, the model offers the user the opportunity to select two different time-step lengths--one for early in the simulation and one for later in the simulation. The time for changing time-step length is also a user-input variable. Generally, the early time-step length needs to be smaller than the limit specified in equation i7. The user may find by experimentation with a particular model configuration that an early time-step length that slightly exceeds this limit may be suitable. Depending on the model-input configuration, the time-step length for later in the simulation may be considerably larger than the early timestep length.

The upper limit on time-step length required by the explicit method can result in lengthy model-execution time. The following equation gives an estimate of computerexecution time required for a simulation, using a PRIME 9955 computer $^{1}$ :

\footnotetext{
${ }^{1}$ The use of trade names in this report is for identification purposes only and does not imply endorsement by the U.S. Geological Survey.
}

$$
C P U=\frac{(N T S)(N C L)}{(V)},
$$

where

$$
\begin{aligned}
C P U= & \begin{array}{l}
\text { computer central processing time, } \\
\text { in seconds; }
\end{array} \\
N T S= & \text { number of time steps; } \\
N C L= & \begin{array}{l}
\text { number of finite-difference cells; } \\
\text { and }
\end{array} \\
V= & \text { a variable. }
\end{aligned}
$$

It was found by experimentation that the value of $V$ ranges from 1,700 to 10,000 , depending on the simulation. The value for $V$ becomes larger (approaching 10,000) as the simulation time is increased.

\section{Format For Model-Input Data Files}

Example model-input data files are shown in figures 5 through 9. These input files are, to a large extent, self-explanatory. The user can follow the format of these files and make modifications to allow for the simulation of a particular test. The uses of model-input data files in figures 5 through 9 are described in the following section.

\section{COMPARISON OF MODEL RESULTS WITH ANALYTICAL SOLUTIONS}

The axisymmetric model can be tested by setting the model-input data to correspond with the assumptions that are built into various analytical solutions and then comparing the results of model simulation with the analytical solution. For analytical solutions that do not take into account processes within the well, model-input data are specified to cause these processes to be negligible.

\section{Steady-State Drawdown in Confined Aquifer}

Under steady-state conditions, the difference in drawdown between points that are located at different distances from the pumped well can be expressed by the Thiem equation (Lohman, 1972). In order for steady-state drawdown to be simulated, use is made of the 
fact that the axisymmetric model automatically sets the last column to be "constant head" (constant zero drawdown). The simulation is run long enough so that drawdown ceases to change with time. Using the zero drawdown at the last column as a datum, the results of the Thiem equation and the axisymmetric model should agree.

The model configuration, the input data file, and results of the Thiem equation and the axisymmetric model are shown in figure 5 . There are no differences in drawdown rounded to four significant figures.

\section{Nonsteady Drawdown in Nonleaky Confined Aquifer}

Under confined conditions, where there is no source of water other than storage, and the aquifer is homogeneous and infinite in areal extent, the drawdown around a pumped well that completely penetrates the aquifer can be expressed by a mathematical formulation developed by Theis (1935). The model configuration, the input data file, and results of the Theis equation and the axisymmetric model are presented in figure 6 . To prevent the possibility of inflow from the constant-head cells, the model is configured to be horizontally extensive enough that there is negligible drawdown near the last column during the time of the simulation. Results of the Theis equation and axisymmetric model are in reasonable agreement.

\section{Drawdown in Leaky Confined Aquifer Ignoring Storage in Confining Layer}

When there is constant pumpage from an infinitely extensive confined aquifer that is overlain (or underlain) by a confining layer through which water can be transmitted to the aquifer from a constant-head source on the other side of the confining layer, the drawdown in the aquifer will induce leakage that eventually will equal pumpage, and drawdown will cease to increase with time. An analytical method used to interpret this, ignoring storage in the confining layer, is referred to as the Hantush-Jacob method (Hantush and Jacob, 1955; Hantush, 1956).
The model configuration, the input data file, and results of the Hantush-Jacob method and the axisymmetric model are presented in figure 7. Both the Hantush-Jacob method and axisymmetric model show a "leveling off" of drawdown during later time.

\section{Drawdown in Leaky Confined Aquifer Considering Storage in Confining Layer}

When there is constant pumpage from an infinitely extensive aquifer that is overlain (or underlain) by a confining layer from which stored water can be transmitted to the aquifer, the drawdown will deviate substantially from drawdown predicted by the Theis equation or the Hantush-Jacob method. An analytical method that deals with storage in the confining layer was developed by Hantush (1960). The model configuration, the input data file, and results of the Hantush method and the axisymmetric model are presented in figure 8.

\section{Drawdown Induced by Partially Penetrating Well in Unconfined Aquifer Considering Delayed Yield}

When a well pumps water from an unconfined aquifer, the relation between drawdown and early time may be the same as that which would be predicted had all water come from pressure storage, instead of the actual dewatering of the porous medium. Later in time, drawdown of the water table occurs, and the relation between drawdown and time follows that which would be predicted from the dewatering process. This "delayed yield" causes an S-shape configuration in the drawdown versus time graph. Neuman (1974; 1975) developed an analytical model to analyze the process of delayed yield and to account for the effect of a well partially penetrating the aquifer. The model configuration, the input data file for the axisymmetric model, and a graph showing results of Neuman's method and the axisymmetric model are presented in figure 9 .

\section{Drawdown in Large-Diameter Well}

The effect of well-casing storage on drawdown is illustrated in figure 10. The conditions of the simulation are identical to the 


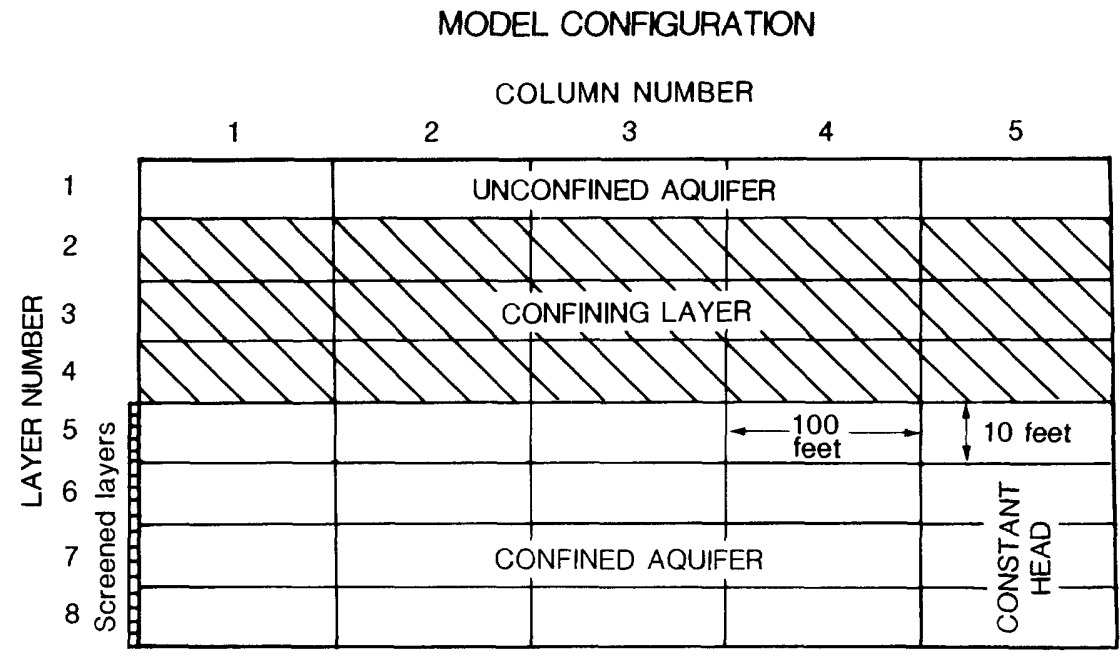

NUMBER OF LAYERS (Z DIRECTION)

INPUT EILE THIEM

NUMBER OF COLUMNS (R DIRECTION)

LENGTH OF FIRST AQUIFER CELL (EEET)

CELL LENGTH MULTIPLIER

SPECIFIC YIELD

WELL DISCHARGE (CUBIC EEET PER SECOND)

WELL RADIUS (EEET)

AREA OF FREE WATER SURFACE IN WELL (SQUARE FEET)

DEPTH BELOW INITIAL WATER TABLE TO PUMP INTAKE (EEET)

ERICTION EACTOR IN WELL CASING

FACTOR IN WELL SCREEN LOSS EQUATION

EXPONENT IN WELL SCREEN LOSS EQUATION

EARLY TIME STEP (SECONDS)

LATER TIME STEP (SECONDS)

CHANGE TIME STEP AT TIME (SECONDS)

PRINTOUT TIMES (SECONDS)
ALLOWABLE ITERATIONS FOR CALCULATING NEW DRAWDOWN IN AQUIFER

ALLOWABLE TRIALS FOR CALCULATING NEW DRAWDOWN IN WELL

NEGLECT FLOW LESS THAN (CUBIC FEET PER SECOND)

IGNORE DRAWDOWN LESS THAN (EEET)

CONVERGENCE CRITERION (FEET)

VARIABLES FOR EACH LAYER:

\begin{tabular}{|c|c|c|c|c|c|}
\hline & LAYER & SCREEN & $\begin{array}{l}\text { HORIZONTAL } \\
\text { HYDRAULIC }\end{array}$ & $\begin{array}{l}\text { VERT ICAL } \\
\text { HYDRAULIC }\end{array}$ & SPECIEIC \\
\hline $\begin{array}{l}\text { LAYER } \\
\text { NUMBER }\end{array}$ & $\begin{array}{c}\text { THICKNESS } \\
\text { (FEET) }\end{array}$ & $\begin{array}{l}\text { IN THIS } \\
\text { LAYER? }\end{array}$ & $\begin{array}{l}\text { CONDUCTIVITY } \\
\text { (EEET/SECOND) }\end{array}$ & $\begin{array}{l}\text { CONDUCTIVITY } \\
\text { (EEET/SECOND) }\end{array}$ & $\begin{array}{l}\text { STORAGE } \\
\text { (1/FEET) }\end{array}$ \\
\hline 1 & 10 & 0 & 0.001 & 0.0001 & 0.00001 \\
\hline 2 & 10 & 0 & .000 & .0000 & .00001 \\
\hline 3 & 10 & 0 & .000 & .0000 & .00001 \\
\hline 4 & 10 & 0 & .000 & .0000 & .00001 \\
\hline 5 & 10 & 1 & .001 & .0001 & .00001 \\
\hline 6 & 10 & 1 & .001 & .0001 & .00001 \\
\hline 7 & 10 & 1 & .001 & .0001 & .00001 \\
\hline 8 & 10 & 1 & .001 & .0001 & .00001 \\
\hline
\end{tabular}

Drawdown, in feet:

\begin{tabular}{|c|c|c|c|c|c|}
\hline & at $r=51$ feet & $r=151$ feet & $r=251$ feet & $r=351$ feet & $r=451$ feet \\
\hline Thiem equation & 4.336 & 2.177 & 1.166 & 0,499 & 0.000 \\
\hline Axisymmetric & 4.336 & 2.177 & 1.166 & 0.499 & 0.000 \\
\hline
\end{tabular}

(where $r$ = distance to center of well)

Figure 5. Model configuration, input data file, and drawdown results determined from Thiem equation (Lohman, 1972) and axisymmetric model. 


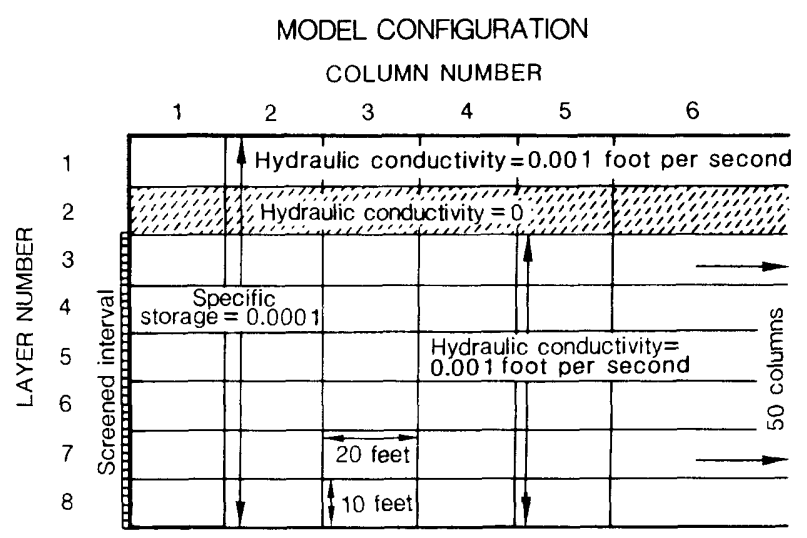

INPUT FILE THEIS

DIRECTION)

LENGTH OF FIRST AQUIFER CELL (FEET)

LENGTH OF FIRST AQUIFER

CELL LENGTH MULTI

WELL DISCHARGE (CUBIC FEET PER SECOND)

WELL DISCHARGE (CUBI

WELL RADIUS (FEET)
AREA OF FREE WATER SURFACE IN WELL (SQUARE FEET)

DEPTH BELOW INITIAL WATER TABLE TO PUMP INTAKE (FEET)

FRICTION FACTOR IN WELL CASING

FACTOR IN WELL SCREEN LOSS EQUATION

EXPONENT IN WELL SCREEN LOSS EQUATION

EARLY TIME STEP (SECONDS)

LATER TIME STEP (SECONDS)

CHANGE TIME STEP AT TIME (SECONDS)

PRINTOUT TIMES (SECONDS)

50.0200 .0

ALLOWABLE ITERATIONS FOR CALCULATING NEW DRAWDOWN IN AQUIFER

ALLOWABLE TRIALS FOR CALCULATING NEW DRAWDOWN IN WELI

NEGLECT ELOW LESS THAN (CUBIC FEET PER SECOND)

IGNORE DRAWDOWN LESS THAN (FEET)

CONVERGENCE CRITERION (FEET) VARIABLES FOR EACH LAYER:

$\begin{array}{ccc}\text { LAYER } & \text { LAYER } & \text { SCREEN } \\ \text { THICKNESS } & \text { IN THIS } \\ \text { NUMBER } & \text { (FEET) } & \text { LAYER? } \\ 1 & 10 & 0 \\ 2 & 10 & 0 \\ 3 & 10 & 1 \\ 4 & 10 & 1 \\ 5 & 10 & 1 \\ 6 & 10 & 1 \\ 7 & 10 & 1 \\ 8 & 10 & 1\end{array}$

HORIZONTAL VERTICAL

HYDRAULIC HYDRAULIC

CONDUCTIVITY CONDUCTIVITY

(FEET/SECOND)

(FEET/SECOND)

0.001

.000

.001

.001

.001

.001

.001

0.001

.000
.001
.001

.001

.001

.001

.001

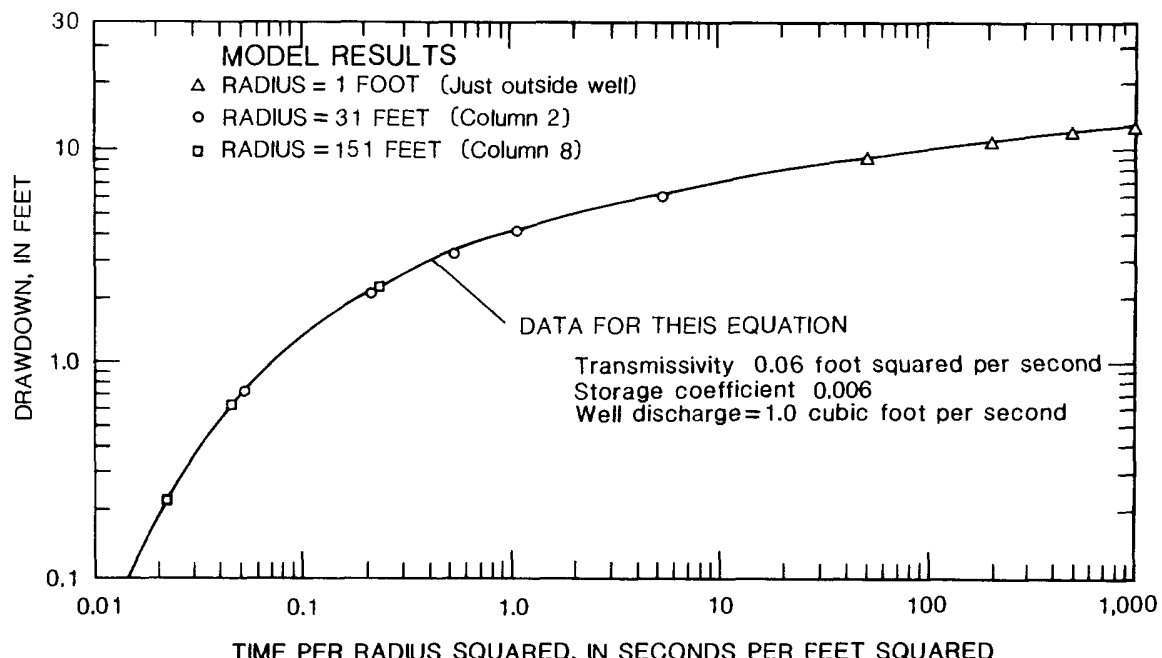

TIME PER RADIUS SQUARED, IN SECONDS PER FEET SQUARED

Figure 6. Model configuration, input data file, and graphical results of drawdown determined from the Theis (1935) equation and the axisymmetric model. 
MODEL CONFIGURATION
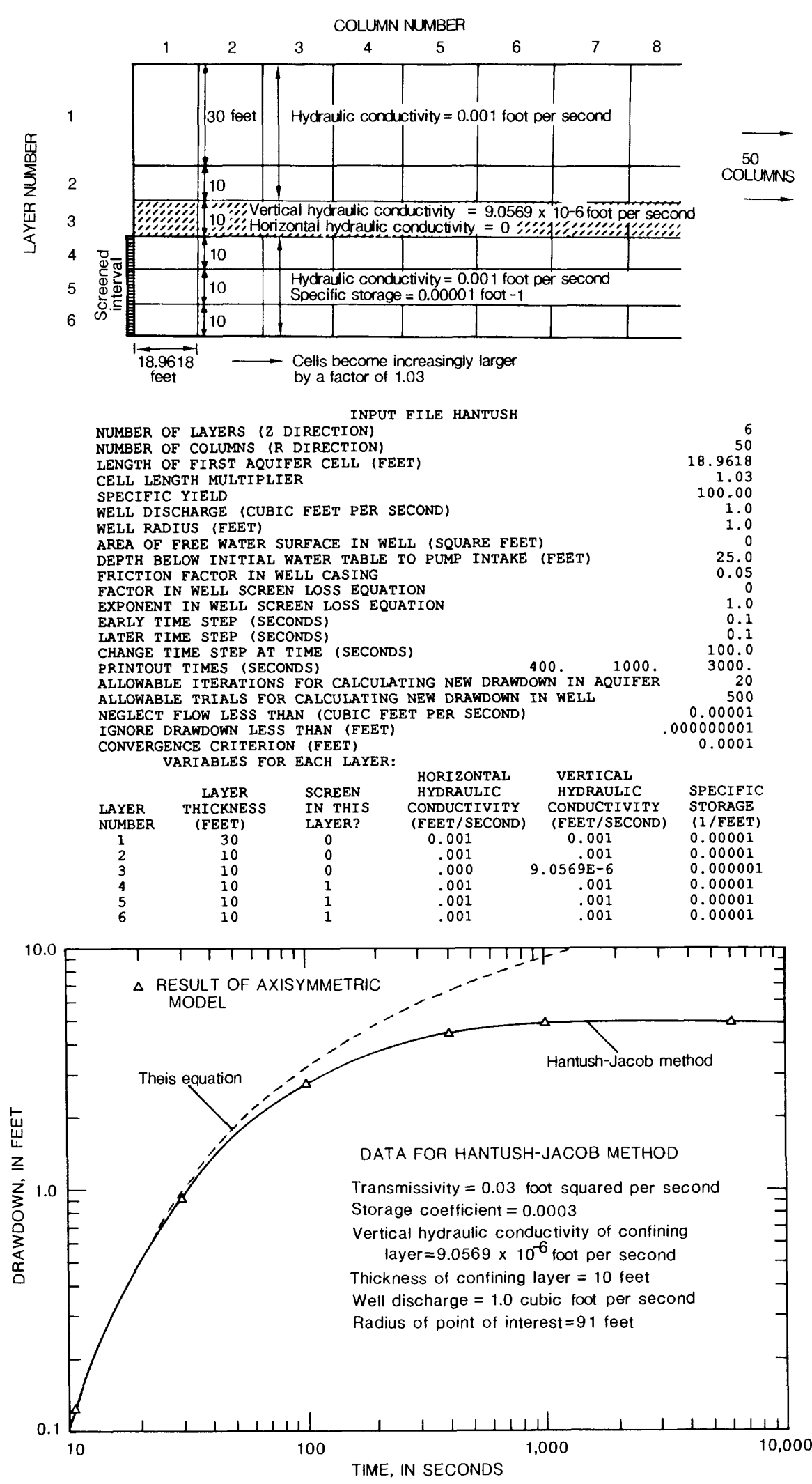

Figure 7. Model configuration, input data file, and graphical results of drawdown determined from the Hantush-Jacob method (Hantush and Jacob, 1955; Hantush, 1956) and the axisymmetric model. 
MODEL CONFIGURATION

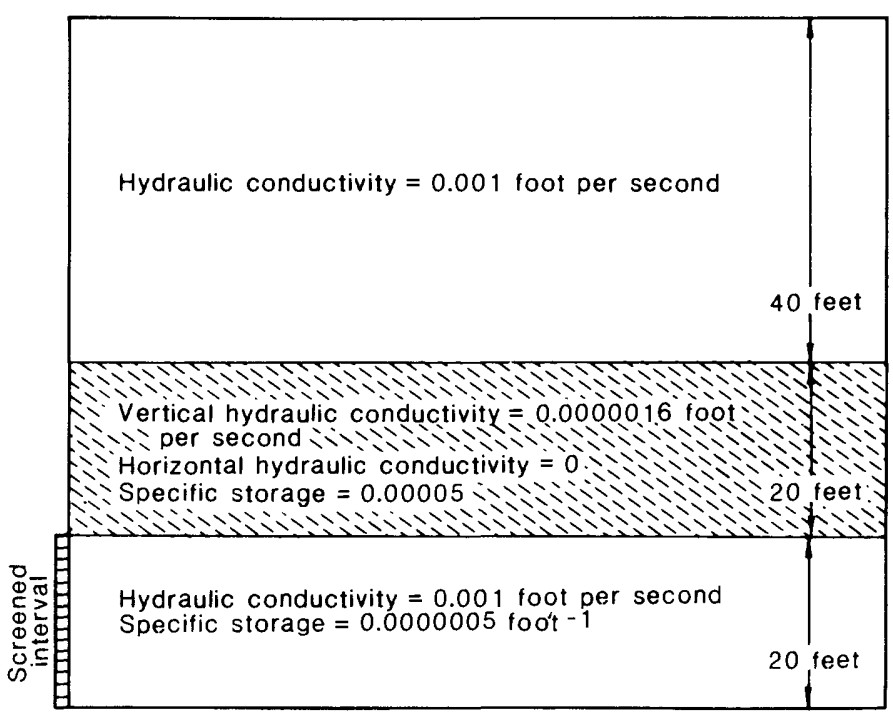

Note: discretization in the horizontal and vertical are shown on the input data file
INPUT FILE HANTUSH2: SIGNIFICANT STORAGE IN CONFINING LAYER NUMBER OF LAYERS (2 DIRECTION)

LENGTK OF FIRST AOUIFER CELL (FEET)

CELL LENGTH MULTIPLIE

SELLL DISCHALE ICUBIC FEET PER SECOOD)

MELL RADIUS (TEET)

SORFACE IN WELL (SOUARE FEET)

FRICTION FACTOR IN MELL CASING

EXPORENT IN MELL, SCREEN LOSS EOUATION

EARLY TIME STEP (SECONDS)

CHANGE TIME STEP AT TIME) (SECOND)

PRINTOUT TIMES (SECONDS) (SECOND) $1.25 \quad 2.50$

ALLOWABLE ITERATIONS FOR CALCULATING NEW DRAWDOWN IN AQUTFE NEGLECT FLON LESS THAN (CUDTC FEET PED SECOWN

IGNORE DRAWDOWN LESS THAN (FEET)

CONVERGENCE CRITERION (FEET)

$\begin{array}{cc}\begin{array}{c}\text { LAYER } \\ \text { NUMBER }\end{array} & \begin{array}{c}\text { LAYER } \\ \text { THICKNESS } \\ \text { (FEET) }\end{array} \\ 1 & 30.00 \\ 2 & 10.00 \\ 3 & 6.80 \\ 4 & 4.60 \\ 5 & 3.00 \\ 6 & 2.00 \\ 7 & 1.30 \\ 8 & 0.90 \\ 9 & 0.55 \\ 10 & 0.35 \\ 11 & 0.25 \\ 12 & 0.15 \\ 13 & 0.10 \\ 14 & 0.10 \\ 15 & 0.30 \\ 16 & 0.80 \\ 17 & 1.90 \\ 18 & 4.90 \\ 19 & 12.00\end{array}$

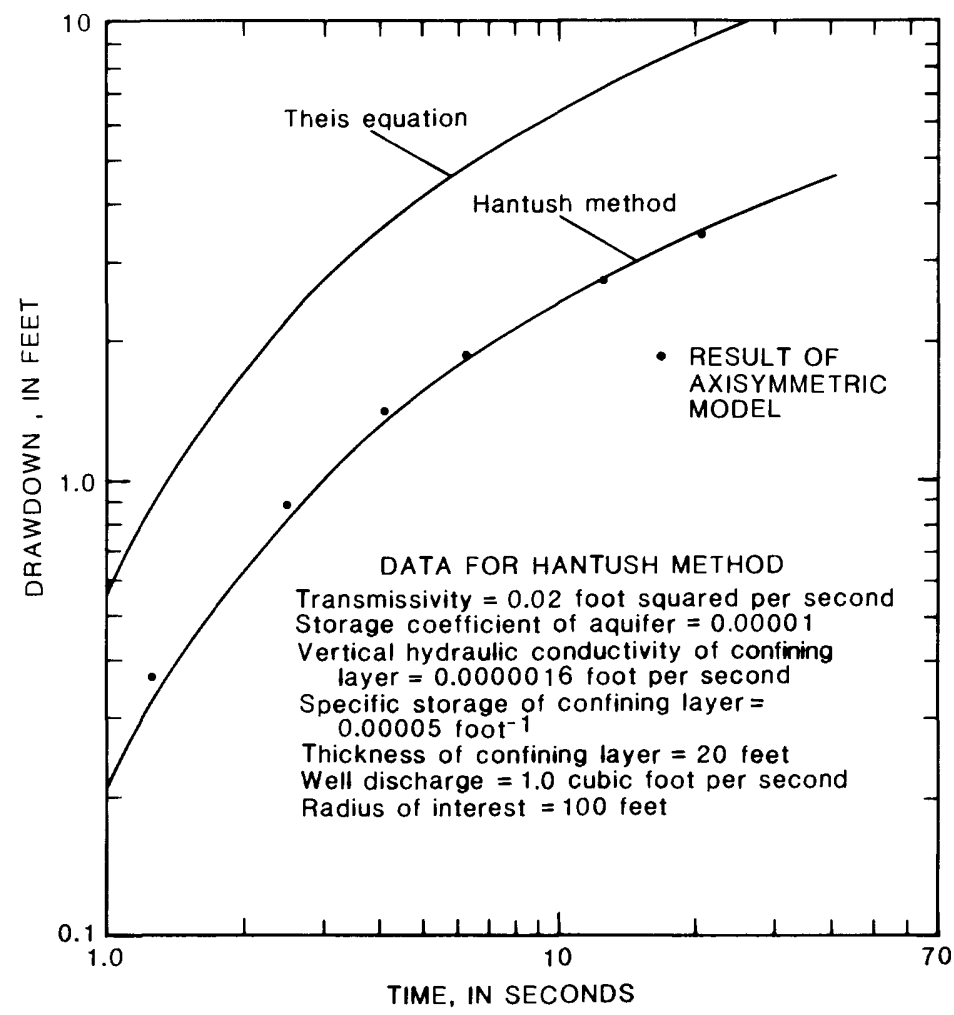

Figure 8. Model configuration, input data file, and graphical results of drawdown determined from the Hantush method (Hantush, 1960) considering storage in confining layer and the axisymmetric model. 

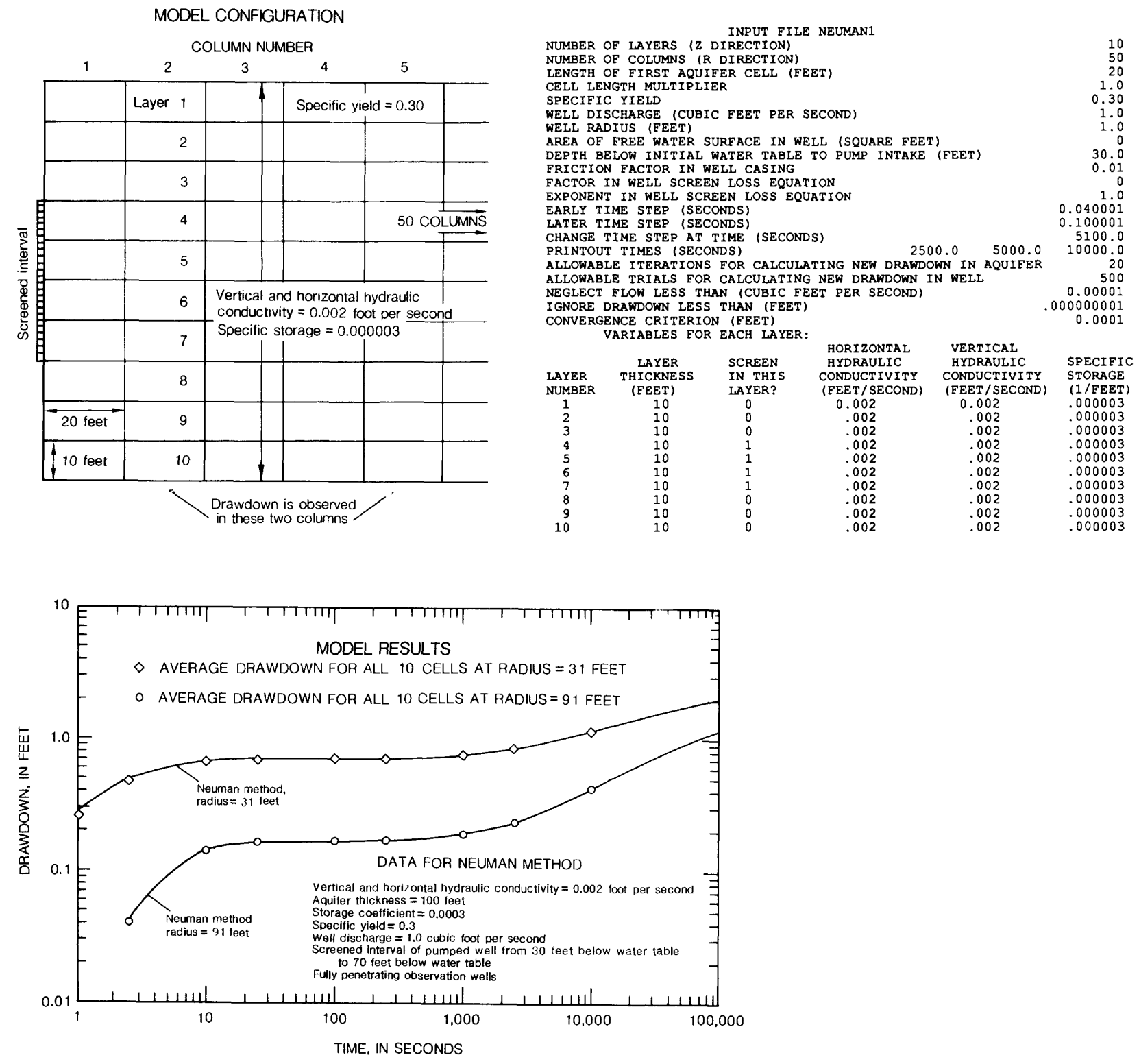

Figure 9. Model configuration, input data file, and graphical results of drawdown determined from the Neuman method (Neuman, 1974; 1975) and the axisymmetric model.

assumptions upon which the Theis equation is based, except some water is obtained from wellcasing storage. Results of simulations show deviation from the Theis curve for the drawdown in the well and for the drawdown at a point 16.5 feet from the well. Results of an analytical method by Papadopulos and Cooper (1967) for determining drawdown in a largediameter well also are shown. All results show a convergence with the Theis equation later in time.

\section{COMPARISON OF MODEL RESULTS WITH RESULTS OF ANOTHER NUMERICAL MODEL}

Reilly (1984) showed results of the simulation of drawdown near a well pumping from an unconfined aquifer that is underlain by a thin confining layer and by a deeper confined aquifer. The model configuration can be summarized as follows: 


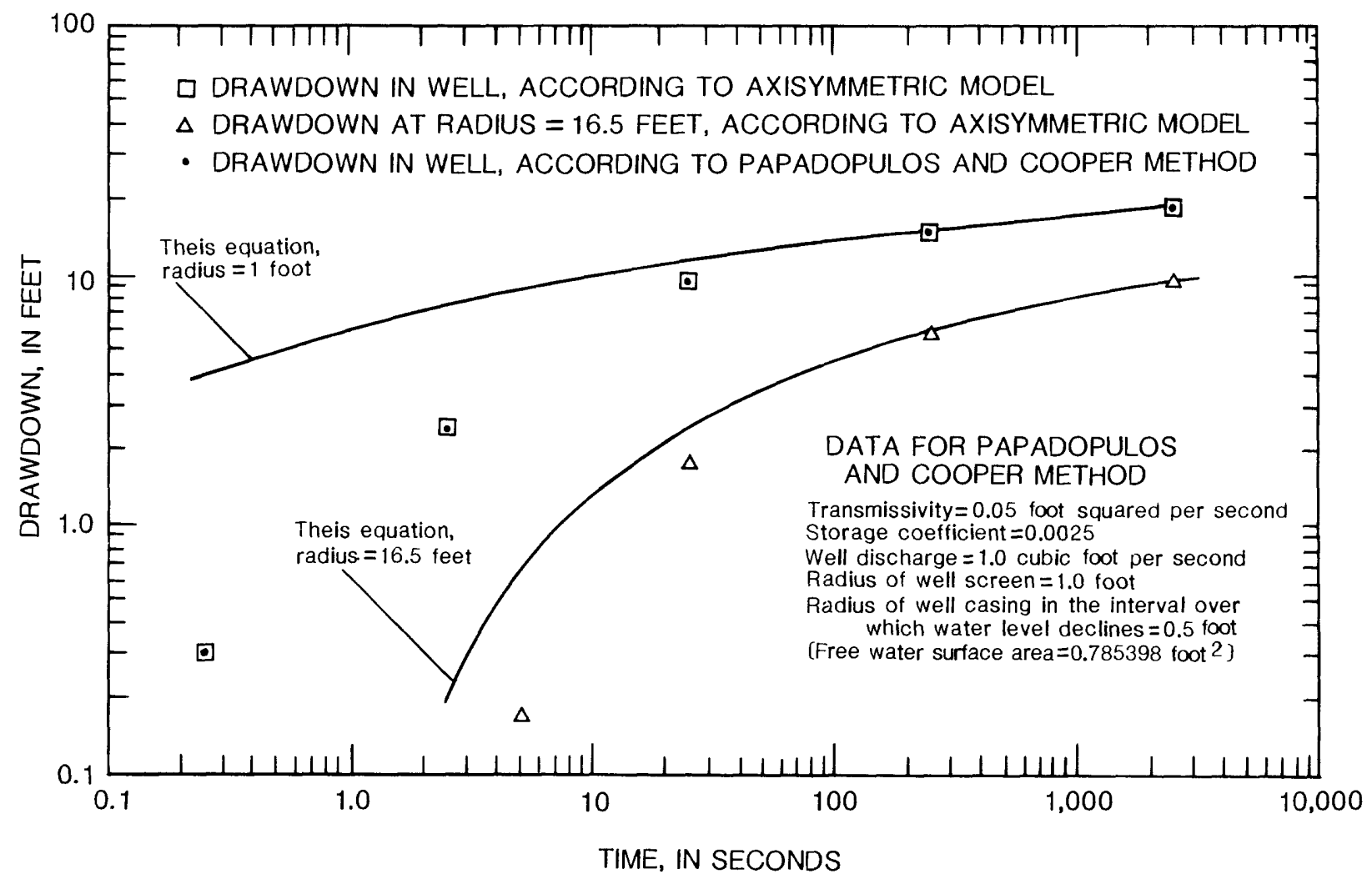

Figure 10. Relation between drawdown and time within and near a pumped well that has 0.785398 square foot of free water surface.

\begin{tabular}{lccc}
\hline & $\begin{array}{c}\text { Horizontal } \\
\text { hydraulic } \\
\text { conductivity } \\
\text { (feet) }\end{array}$ & $\begin{array}{c}\text { Vertical } \\
\text { (feet per second) }\end{array}$ & $\begin{array}{c}\text { hydraulic } \\
\text { conductivity } \\
\text { (feet per second) }\end{array}$ \\
\hline $\begin{array}{l}\text { Upper aquifer } \\
\text { Confining layer }\end{array}$ & 75 & 0.003125 & 0.0003125 \\
Lower aquifer & 10 & 0.000000116 & 0.0000000116 \\
& 190 & 0.000579 & 0.000016 \\
& specific yield $=0.25 ;$ & & \\
& specific storage $=0.000001$ foot ${ }^{-1}$; & \\
& screened interval $=50$ to 75 feet; \\
& pumping rate $=1.0$ cubic foot per second; and \\
time of interest $=3,197$ seconds. & \\
\hline
\end{tabular}


A comparison of results between the numerical model of Reilly (1984) and the axisymmetric model is present in figure 11 .

\section{COMPLICATIONS INDUCED BY WELL CHARACTERISTICS}

Most mathematical models for interpreting the results of aquifer tests are based on certain assumptions concerning the processes occurring near the well. These assumptions may include that: (1) the pumped well can be considered a continuous line sink; (2) inflow to this sink occurs at uniform flux along the length of the sink [volume/((time)(length)]]; (3) the hydraulic head along this sink is uniform; (4) the hydraulic head obtained by measuring the water level in the well represents the hydraulic head along this sink; and (5) the water obtained from well storage is negligible. The degrees by which these assumptions are not valid may be large enough to lead to substantial errors in interpretation of aquifer-test data. The following examples show ways that the axisymmetric model considers complexities in ground-water flow caused by the pumped well.

The drawdown within and near a pumped well that fully penetrates a homogeneous, isotopic, confined aquifer is shown in figure 12. Hydraulic-head loss due to pipe-flow friction and variation in velocity along the casing is substantial. The drawdown increases from 19.1 to 26.4 feet, from bottom to top of the cased interval. This induces considerable vertical variation in drawdown in the aquifer. The conditions of figure 12 are similar to those of Cooley and Cunningham (1979, fig. 5C). Results are in reasonable agreement.

The drawdown induced near a pumped well that penetrates a homogenous, isotropic, unconfined aquifer is shown in figure 13 . Hydraulic-head loss due to pipe-flow friction and variation in velocity along the casing is substantial. Along the 100 feet of screened interval, there is an increase in drawdown of 3.74 feet. There is an additional hydraulic-head loss of 2.74 feet from the top of the screened interval to the pump intake. The drawdown that would be obtained by measuring the water level in the well differs from the drawdown at depth by 2.74 to 6.48 feet, depending on the depth considered. Furthermore, the hydraulic-head loss within the well at depth is not equal to the hydraulic-head loss at the outside of the well because of well-screen loss. Because drawdown at the well is greatest at the top part of the screened interval, there is greater driving force there for inflow to the well. The inflow is about 1.94 times greater at the top than at the bottom.

The drawdown near a pumped well that is open to three different water-bearing formations that are separated by confining layers is illustrated in figure 14. All layers are anisotropic. Drawdowns at the three screened intervals are $21.28,19.85$, and 19.38 feet, descending with depth. Due to these differences and to the separation of the screened intervals, the drawdown in the aquifer system varies considerably with depth in close proximity of the well. Notwithstanding the delayed yield effect near the water table, these variations become slight at a distance of about 150 feet from the well. The pumpage from the upper aquifer zone is 41 percent of the total, whereas the pumpage from the lower aquifer zone is only 28 percent.

\section{POSSIBLE MODEL IMPROVEMENTS}

There may be several modifications or additions to the computer program that can enhance the logistical aspects of running the model or improve the accuracy of model results. Some of these possible improvements are itemized here.

(1) The replacement of the explicit numerical method for calculating drawdown in the aquifer with an implicit method may decrease the need for small time steps and result in shorter execution time.

(2) A more rigorous treatment of head loss across the well screen may improve accuracy of the model. It could be advantageous to allow for a zone of turbulent flow outside the well, the extent of which would be a function of specific discharge (Rorabaugh, 1953).

(3) The utility of the model could be improved if it allowed for simulation of the seepage face and for the pump intake to be located below the top of the screen.

(4) The allowance for variation in pumping 


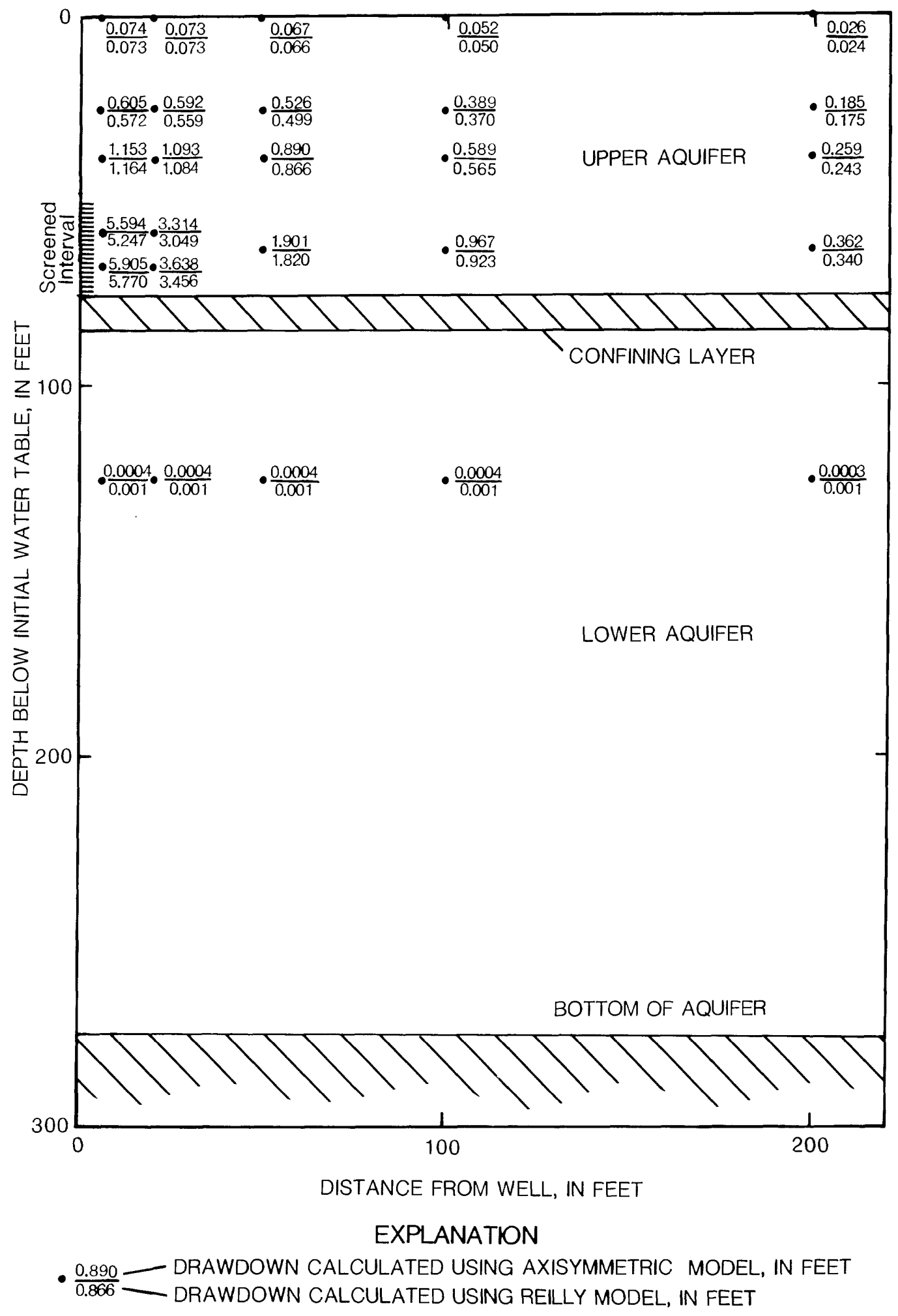

Figure 11. Results of drawdown computed by the Reilly model and the axisymmetric model. 


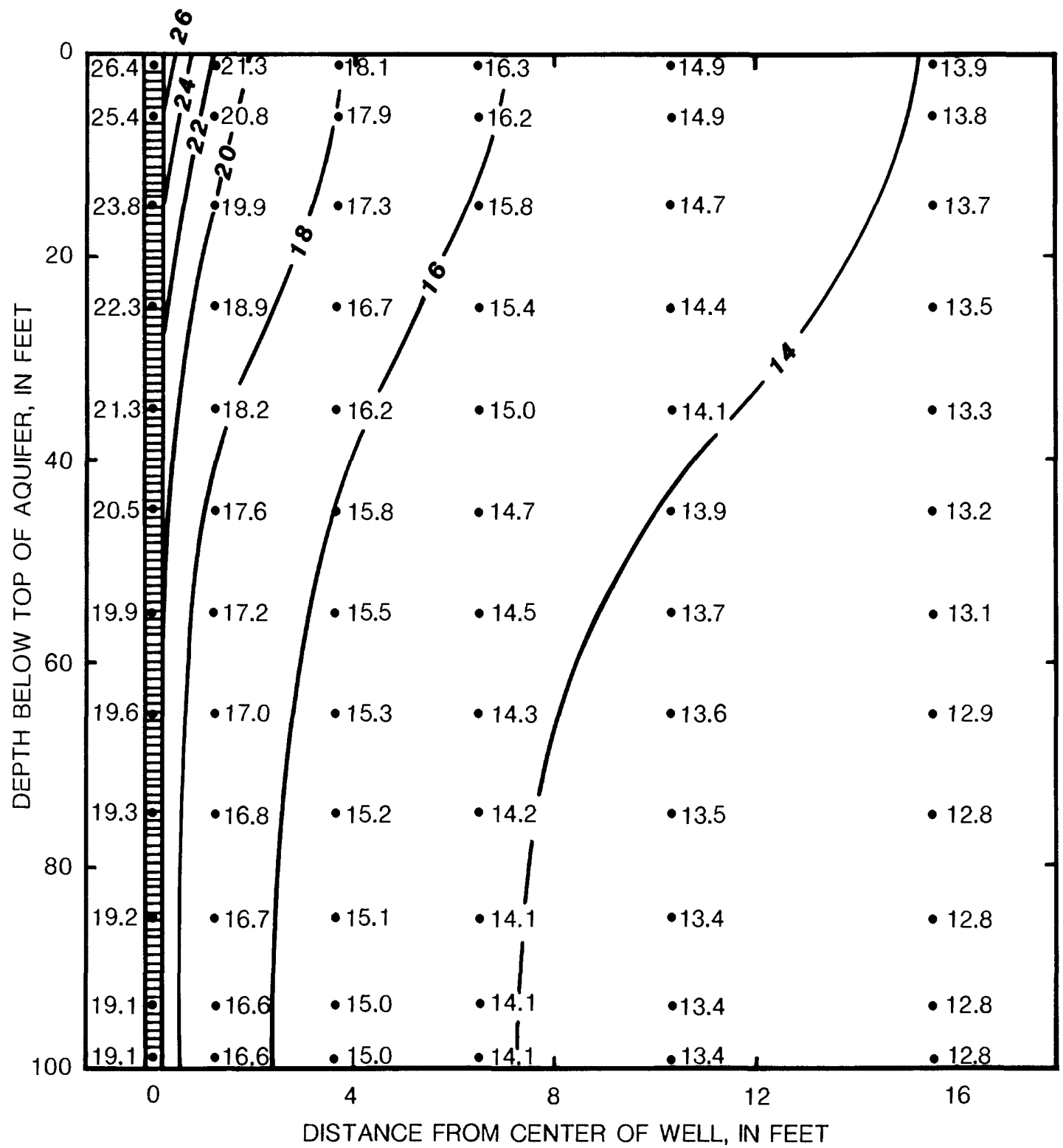

EXPLANATION

LINE OF EQUAL DRAWDOWN-

- 16- Interval 2 feet

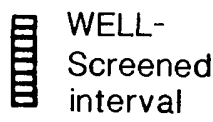

$\bullet 13.5$

DATA POINT-

Number is

drawdown, in feet

Figure 12. Drawdown in and near a pumped well that fully penetrates a homogeneous, isotropic, confined aquifer under conditions similar to Cooley and Cunningham (1979, fig. $5 \mathrm{C}$ ) [hydraulic conductivity $=0.0016677$ foot per second; aquifer thickness $=100$ feet; screened interval $=$ entire aquifer thickness; well radius $=0.25$ foot; well discharge $=2.00$ cubic feet per second; friction factor $(F)$ in well casing $=0.05$; the factor in well-screen loss equation $(C M)=0.10533$; the exponent in well-screen loss equation $(C M)=$ 2.0; pumping time of sufficient duration for drawdown to equilibrate; distance to constant-head boundary = 15,500 feet]. 


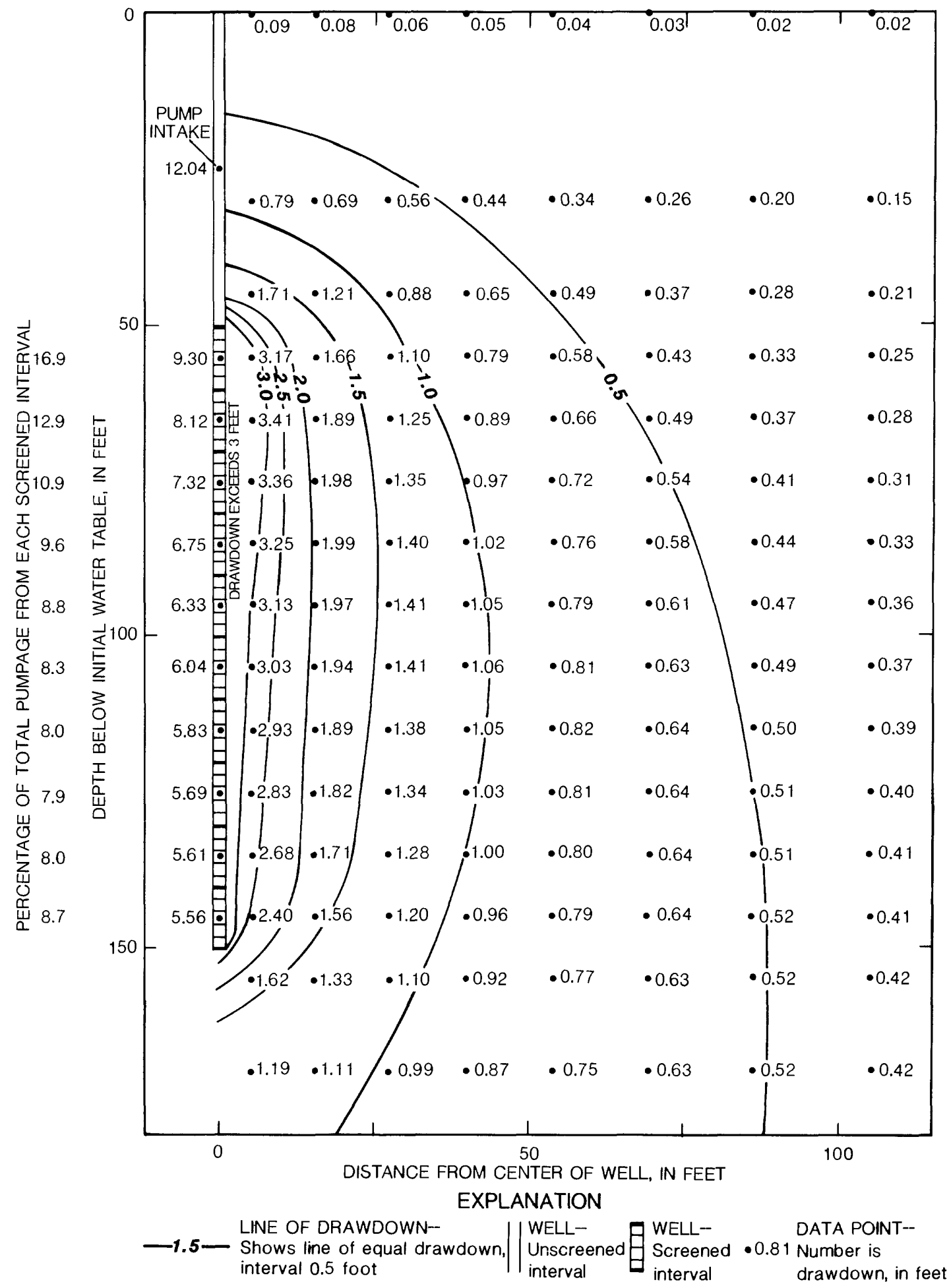

Figure 13. Drawdown in and near a pumped well that is open to homogeneous, isotropic, unconfined aquifer [hydraulic conductivity $=0.002$ foot per second; saturated thickness $=180$ feet; specific storage $=$ 0.00001 foot $^{-1}$; apparent specific yield $=0.25$; well radius $=0.25$ foot; screened interval $=50$ to 150 feet below initial water table; well discharge $=1.5$ cubic feet per second; friction factor $(F)$ in well casing $=0.05$; the factor in well-screened loss equation $(C W)=4.0$; the exponent in well-screen loss equation $(C M)=2.5$; time $=500$ seconds] 


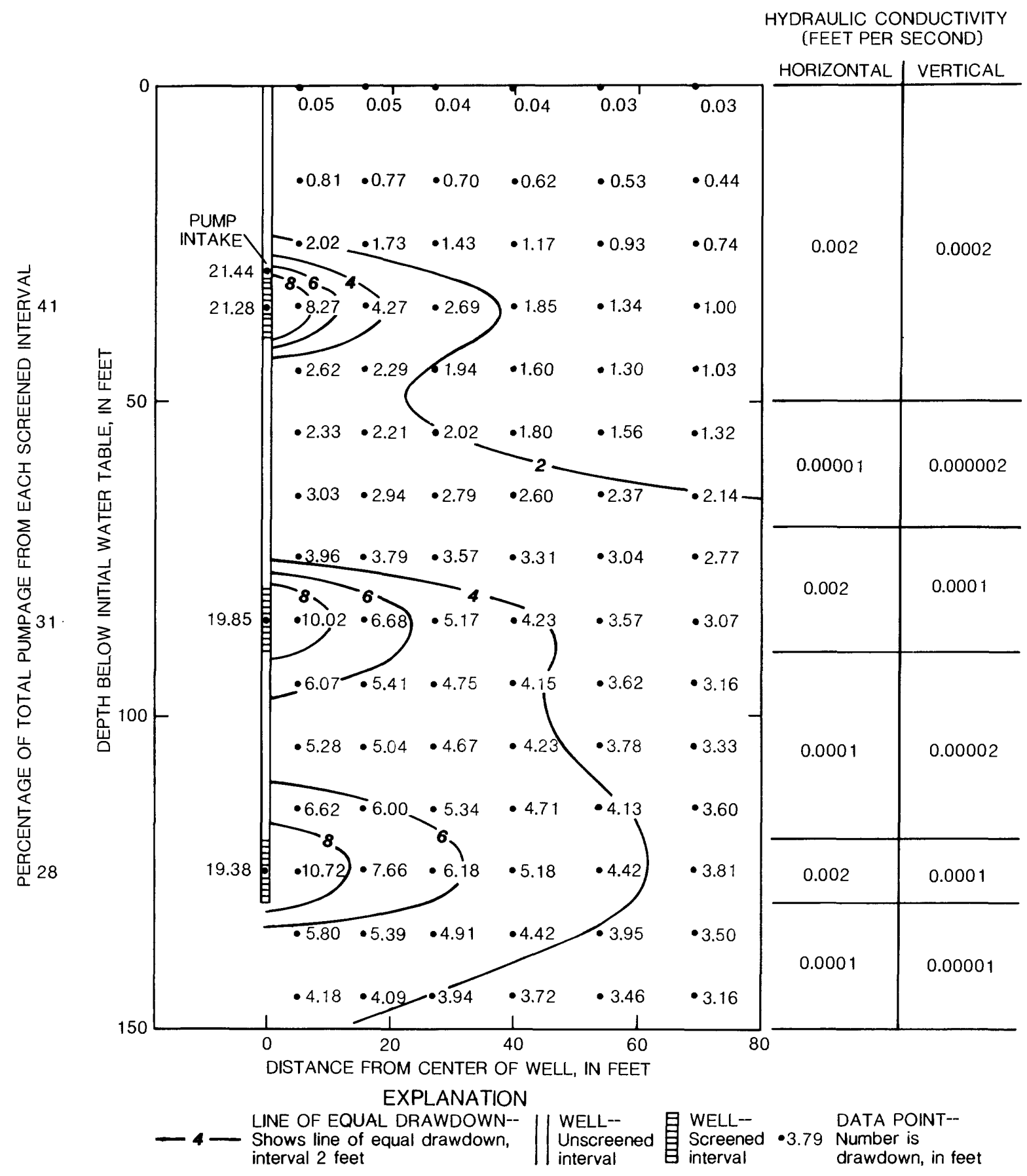

Figure 14. Drawdown in and near a pumped well that is open to three different zones in a heterogeneous, anisotropic aquifer system [specific storage $=0.00001$ foot $^{-1}$; apparent specific yield $=0.2$; well radius $=$ 0.25 foot; well discharge $=1.3$ cubic feet per second; friction factor $(F)$ in well casing $=0.023$; hydraulichead loss across well screen $=0$; time $=1,000$ seconds]. 
rate with time may improve the applicability of the model because pump tests include incidental fluctuation in pumping rate and monitoring during recovery periods.

\section{SUMMARY}

The axisymmetric finite-difference model can simulate drawdown in three dimensions in and around a pumped well. Well properties that can be simulated include well-casing storage, hydraulic-head loss across the well screen, and hydraulic-head variation along the length of the well bore due to pipe-flow friction and nonuniform velocity. The model allows for partial well penetration and for multiple screened intervals. The fraction of total inflow to the well that is allocated to each aquifer layer is a variable that is calculated in each time step. Aquifer properties that can be simulated include confined conditions (leaky or nonleaky), unconfined conditions, vertical-horizontal anisotropy, and vertical variations in hydraulic conductivity.

Horizontal flow is calculated from an integration of Darcy's law to allow for the variation in cross-sectional area from one finitedifference cell to the next. The uppermost layer of finite-difference cells, which represents the upper part of the saturated zone, contributes stored water from specific yield, whereas other cells contribute stored water from specific storage. This representation allows for simulation of the "delayed-yield" effect. Calculation of horizontal flow in the uppermost layer of cells allows for the reduction in crosssectional area (and transmissivity) caused by lowering of the water table.

The model requires horizontal uniformity of hydraulic conductivity, specific yield, and specific storage. The model also requires that the upper layer of cells must be thicker vertically than the maximum drawdown of the water table, and that the seepage face is not simulated. The geometric configuration requires the pump intake to be above the top of the well screen. An upper limit on time-step length required by the explicit method can result in lengthy execution time.

Several different aquifer properties and numerous complexities in the flow system that are caused by well characteristics can be simulated. All characteristics can be allowed for simultaneously. The model was tested by comparing its results with results of published analytical solutions and other mathematical models. The results were generally in good agreement.

\section{SELECTED REFERENCES}

Bouwer, Herman, 1978, Groundwater hydrology: New York, McGraw-Hill, 480 p.

Cooley, R.L., and Cunningham, A.B., 1979, Consideration of energy loss in theory of flow to wells: Journal of Hydrology, v. 43, p. 161-184.

Davis, L.A, and Neuman, S.P., 1983, Documentation and users guide--UNSAT2Variably saturated flow model: U.S. Nuclear Regulatory Commission, NUREG/CR-3390.

Freeze, R.A., and Cherry, J.A., 1979, Groundwater: Englewood Cliffs, N.J., Prentice-Hall, $604 \mathrm{p}$.

Hantush, M.S., 1956, Analysis of data from pumping tests in leaky aquifers: Transactions of American Geophysical Union, v. 37, p. 702-714.

1960 , Modification of the theory of leaky aquifers: Journal of Geophysical Research, v. 65 , no. 11 , p. $3713-3725$.

Hantush, M.S., and Jacob, C.E., 1955, Nonsteady radial flow in an infinite leaky aquifer: Transactions of American Geophysical Union, v. 36, no. 1, p. 95-100.

Jacob, C.E., 1947, Drawdown test to determine effective radius of artesian well: Transactions of the American Society of Civil Engineers, v. 112, p. 1047-1070.

Lohman, S.W., 1972, Ground-water hydraulics: U.S. Geological Survey Professional Paper $708,70 \mathrm{p}$.

McWhorter, D.B., and Sunada, D.K. 1985, Ground-water hydrology and hydraulics: Fort Collins, Colorado, Water Resources Publications, 290 p. 
Neuman, S.P., 1974, Effect of partial penetration on flow in unconfined aquifers considering delayed gravity response: Water Resources Research, v. 10, no. 2, p. 303-312.

1975, Analysis of pumping test data from anisotropic unconfined aquifers considering delayed gravity response: Water Resources Research, v. 11, no. 2, p. 329-342.

Papadopulos, I.S., and Cooper, H.H., 1967, Drawdown in a well of large diameter: Water Resources Research, v. 3, p. 241-244.

Reilly, T.E., 1984, A Galerkin finite-element flow model to predict the transient response of a radially symmetric aquifer: U.S. Geological Survey Water-Supply Paper 2198, 33 p.

Rorabaugh, M.I., 1953, Graphical and theoretical analysis of step-drawdown test of artesian well: Proceedings of American Society of Civil Engineers, v. 79, no. 362, 23 p.
Rushton, K.R., and Redshaw, S.C., 1979, Seepage and groundwater flow--Numerical analysis by analog and digital methods: New York, JohnWiley and Sons, 339 p.

Streeter, V.L., 1950, Steady flow in pipes and conduits, in Rouse, Hunter, ed., Engineering hydraulics: New York, John Wiley and Sons, p. 387-443.

Theis, C.V., 1935, The relation between the lowering of the piezometric surface and the rate and duration of discharge of a well using groundwater storage: Transactions of American Geophysical Union, v. 16, p. 519524.

Wang, H.F., and Anderson, M.P., 1982, Introduction to groundwater modeling-Finite difference and finite element methods: San Francisco, W.H. Freeman and Co., 237 p. 


\section{PROGRAM LISTING}

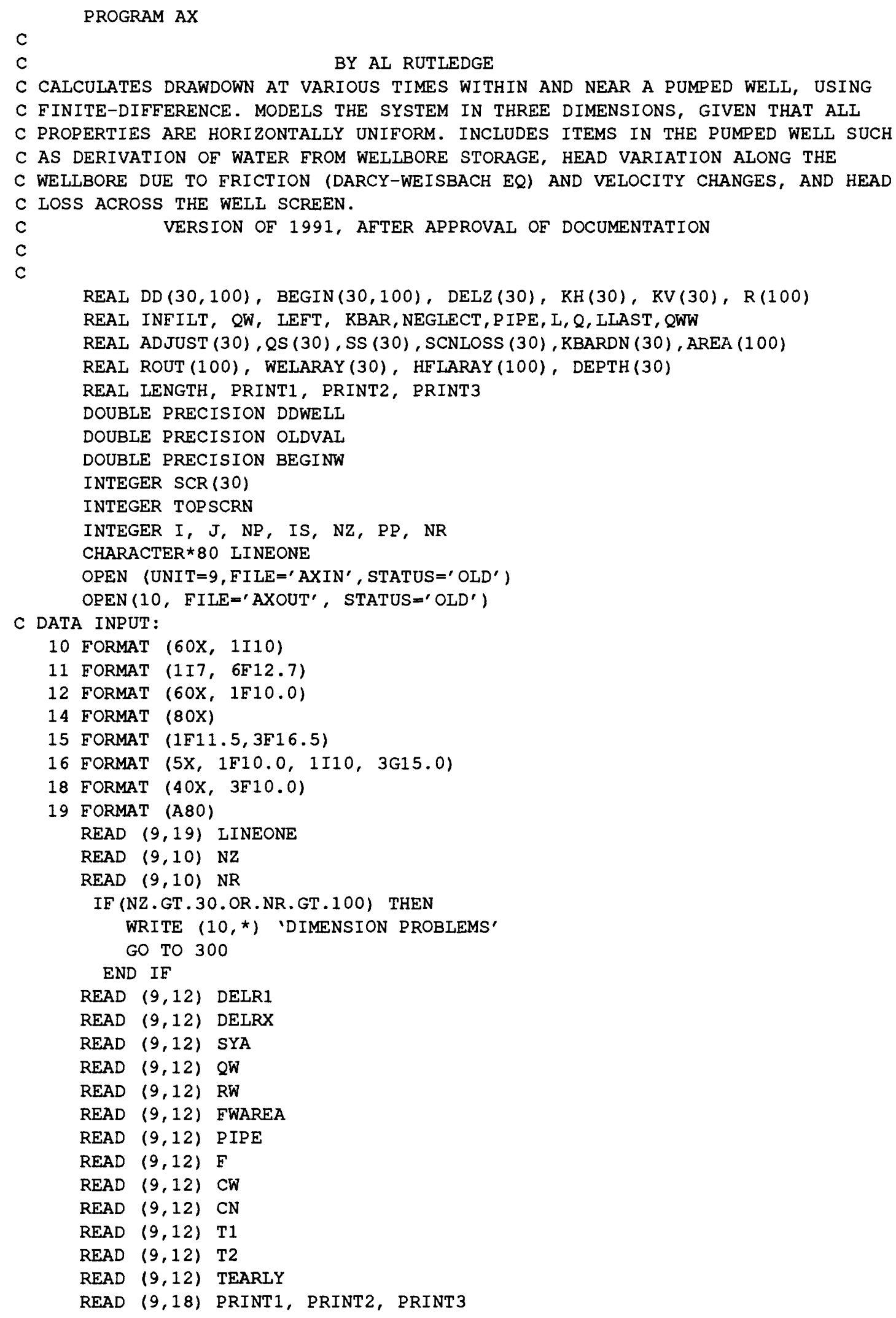




\section{PROGRAM LISTING--Continued}

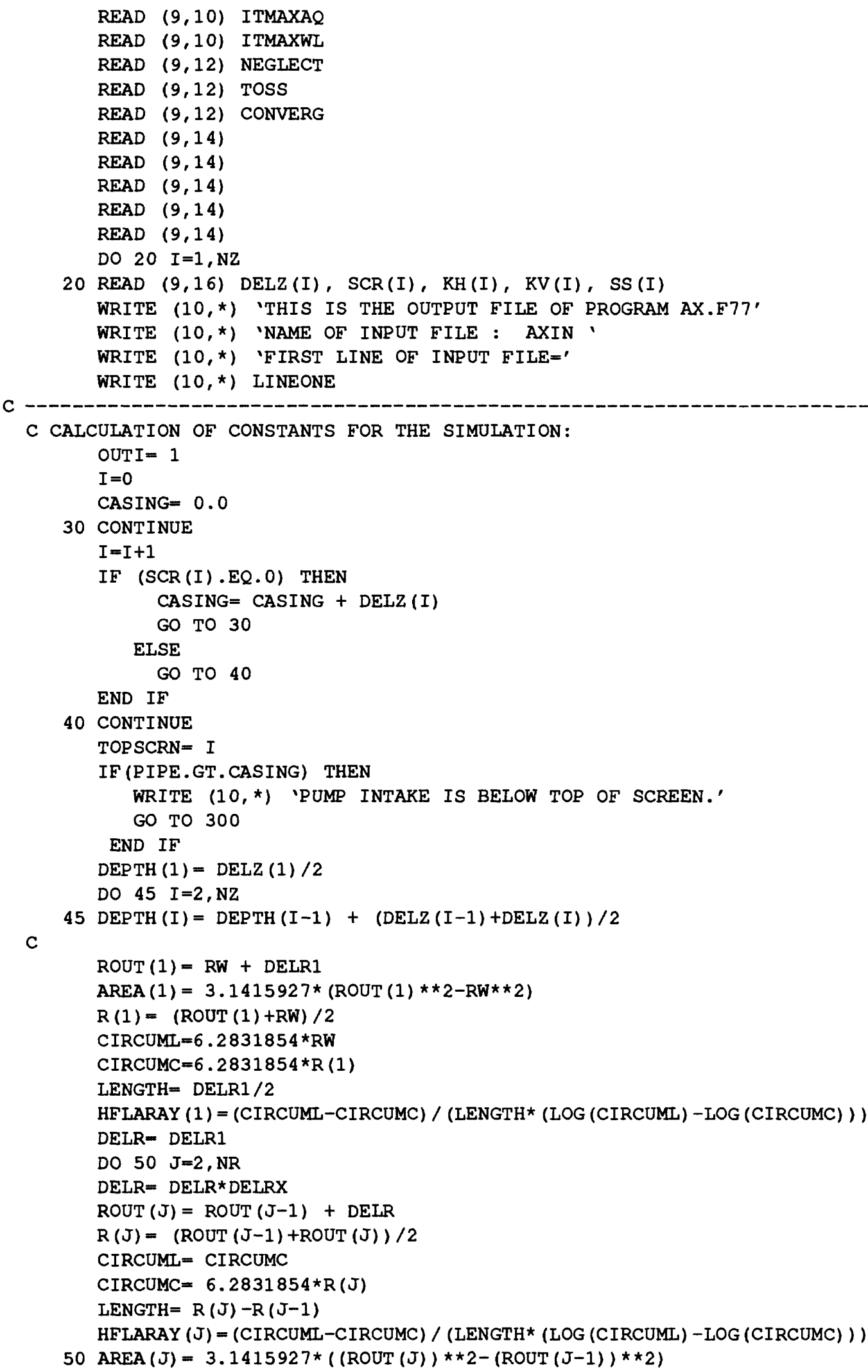




\section{PROGRAM LISTING--Continued}

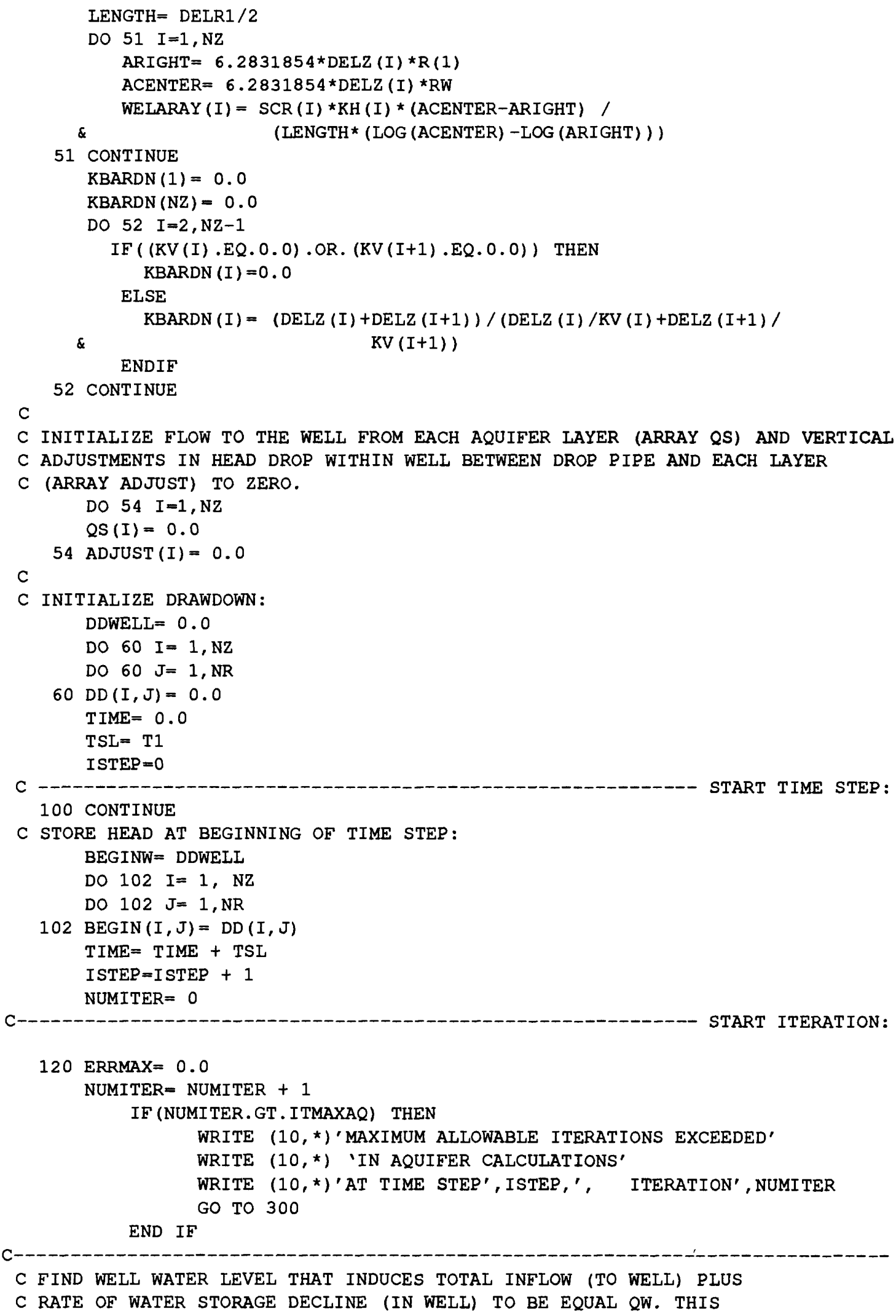




\section{PROGRAM LISTING--Continued}

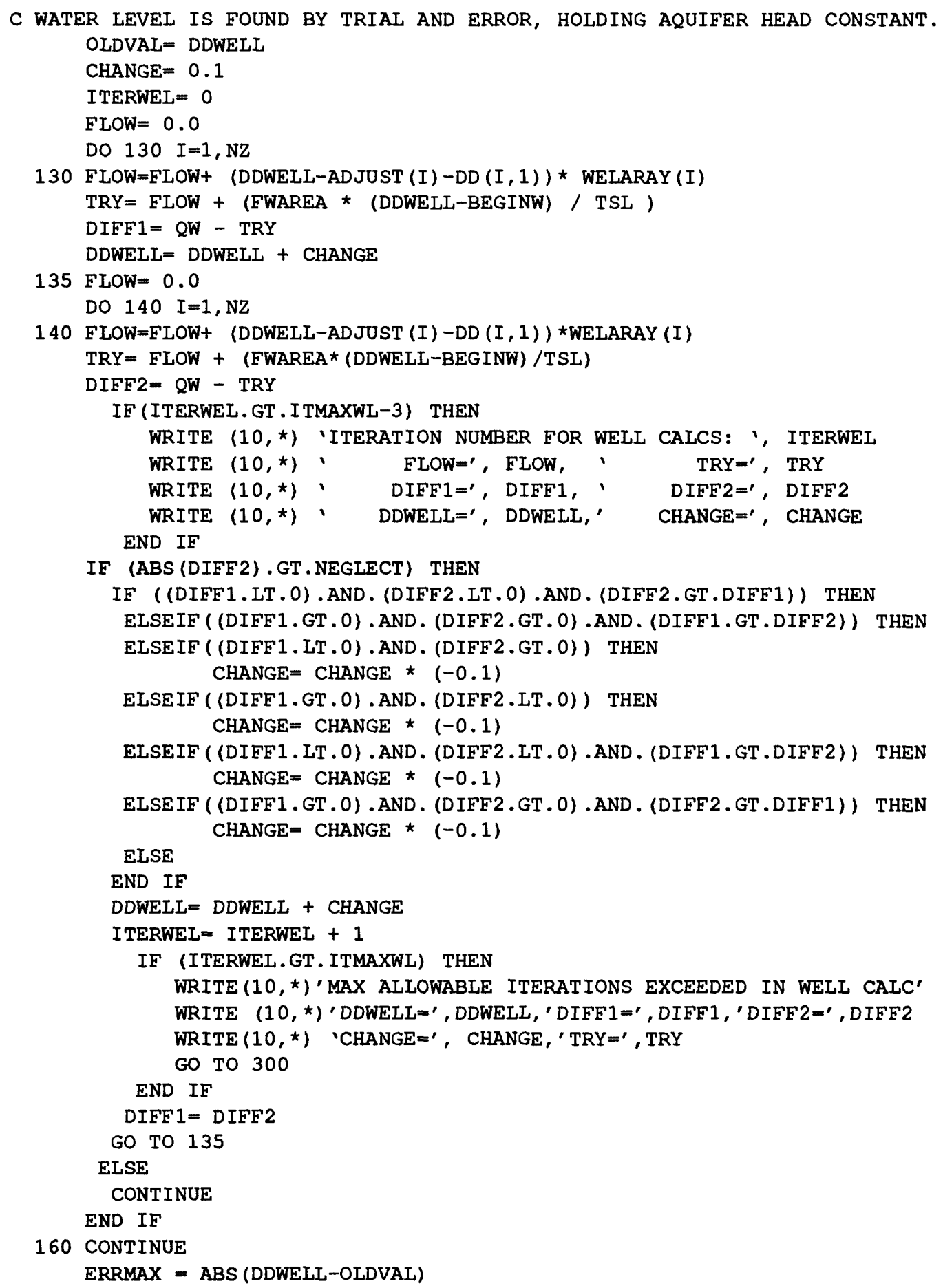




\section{PROGRAM LISTING--Continued}

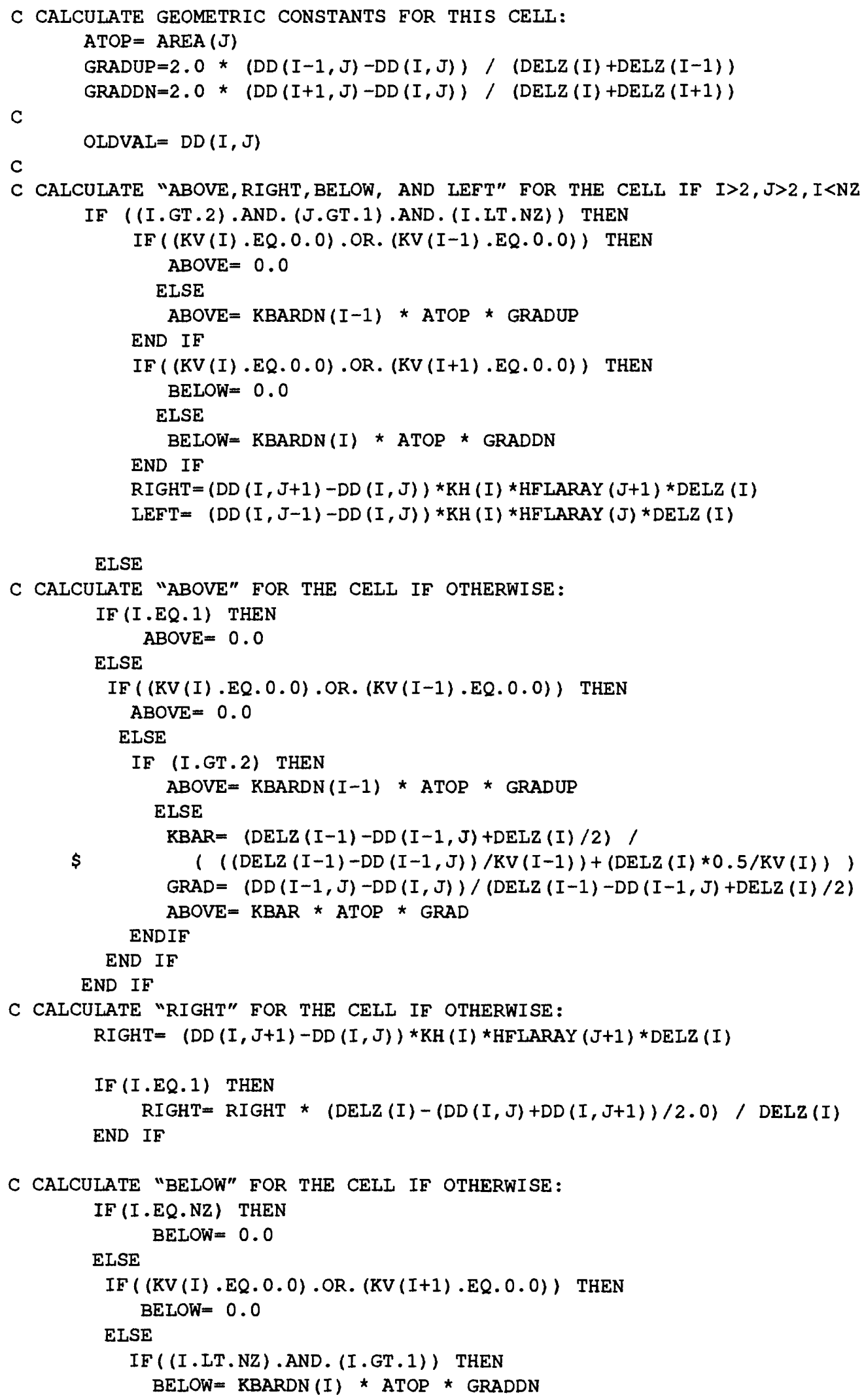




\section{PROGRAM LISTING--Continued}

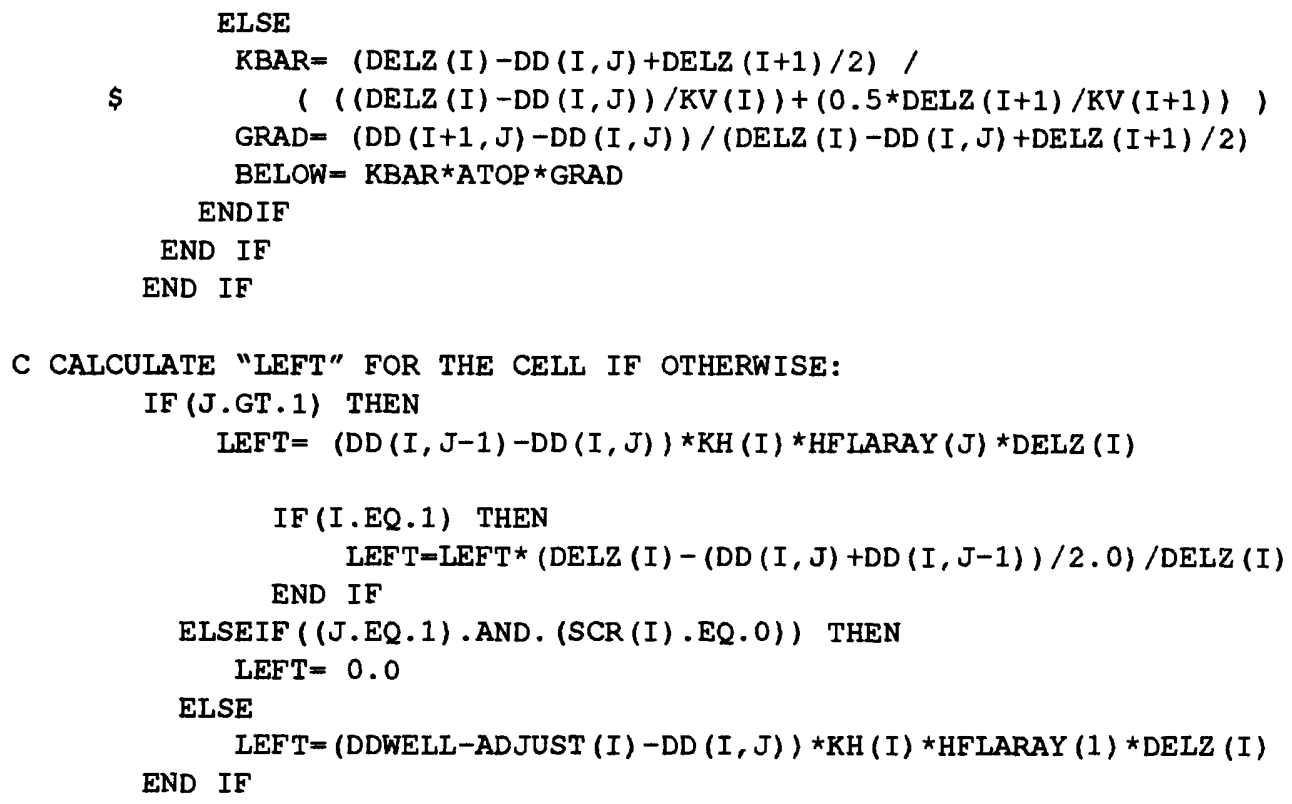

C CALCULATE NEW DRAWDOWN AT THIS CELL, USING 4 COMPONENTS OF FLOW PLUS

C A STORAGE TERM DEPENDENT UPON CELL LOCATION:

IF (I.GT.1) THEN

\&

$\operatorname{DD}(I, J)=\operatorname{BEGIN}(I, J)+($ TSL $*(A B O V E+R I G H T+B E L O W+L E F T)) /$

C CALCULATE CHANGE IN HEAD FOR THIS NODE, AND SET ERRMAX EQUAL TO IT IF

C IT EXCEEDS ALL HEAD CHANGES CALCULATED FOR PREVIOUS NODES: $E R R=(D D(I, J)-O L D V A L)$

IF (ABS (ERR) . GT. ERRMAX) ERRMAX = ABS (ERR)

200 CONTINUE

C DO ANOTHER ITERATION IF CONVERGENCE CRITERION IS EXCEEDED IF (ERRMAX.GT.CONVERG) GO TO 120 


\section{PROGRAM LISTING--Continued}

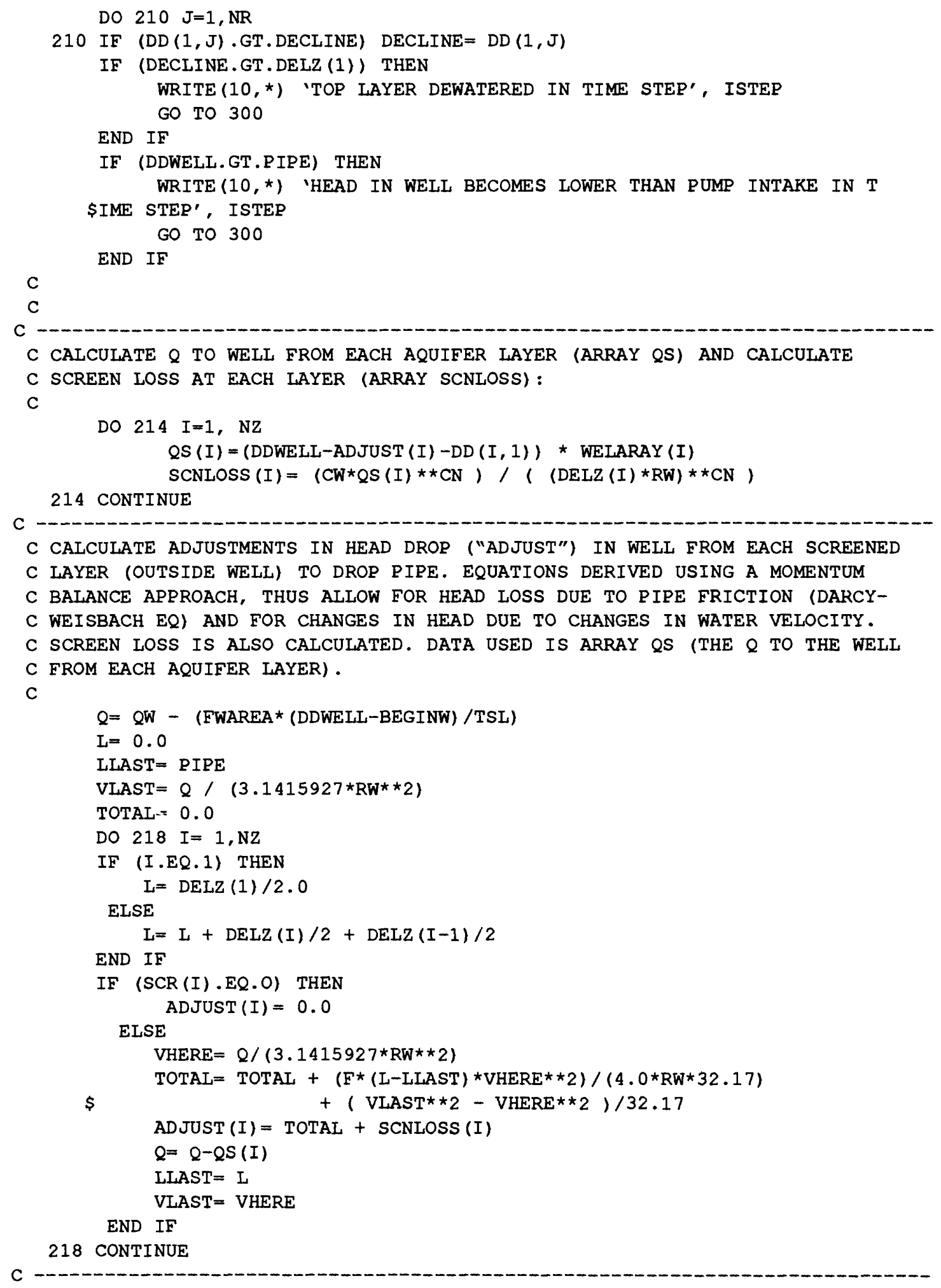

IF (TIME.GE.TEARLY) TSL= T2 


\section{PROGRAM LISTING--Continued}

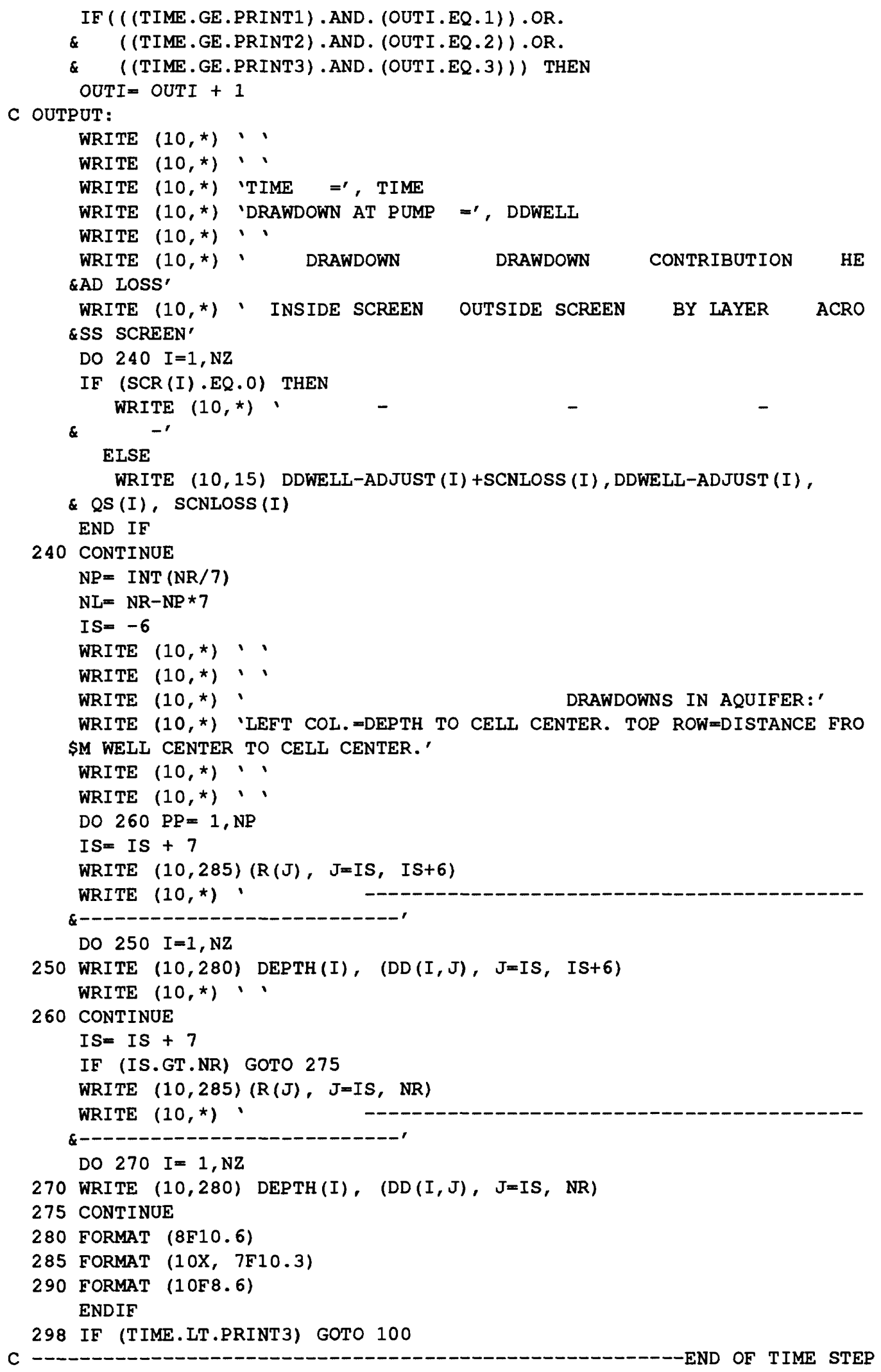


PROGRAM LISTING--Continued

300 CONTINUE

CLOSE (9, STATUS='KEEP')

CLOSE (10, STATUS= 'KEEP')

STOP

END 